Division of Agricultural scie

The Influence
of Modern Man
on the Vegetation
of Yosemite Valley

ROBERT P. GIBBENS - HAROLD F. HEADY

CALIFORNIA AGRICULTURAL

Experiment Station KEARIEY HCRT.CULTURAL
Extension Service

MANUAL 36 FIELD STATION 



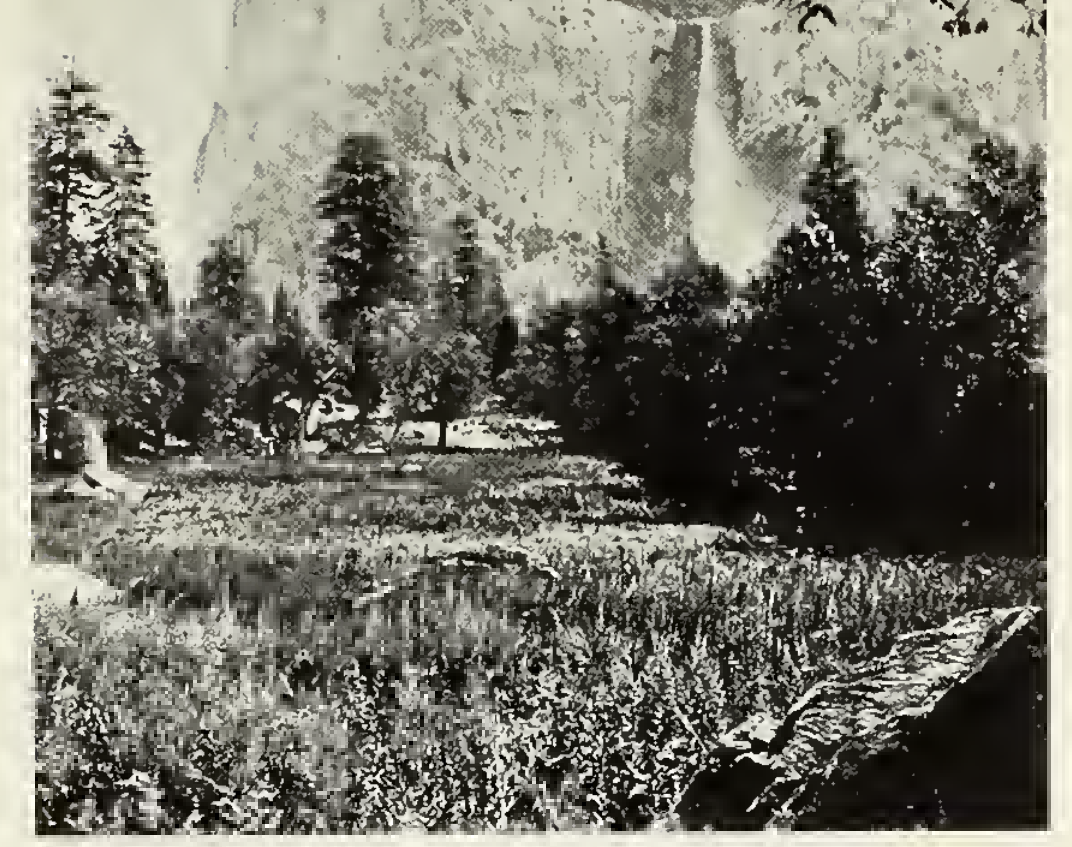

\section{The Influence of Modern Man on the Vegetation of Yosemite Valley}

This publication compares the present vegetation of Yosemite Valley with that existing in 1851 as depicted by early writings and photographs, and discusses the changes-both man-made and natural—which have occurred since then.

UNIVERSITY OF CALIFORNIA • DIVISION OF AGRICULTURAL SCIENCES 


\section{Contents}

INTRODUCTION . . . . . . . . . . . . . . 1

EVENTS AFFECTING THE VEGETATION . . . . . . . . . 2

VEGETATION AT THE TIME OF DISCOVERY . . . . . . . . 6

TREE INCREASE . . . . . . . . . . . . . . . 10

CAUSES OF TREE INCREASE . . . . . . . . . . . . 15

EFFECT OF CUTTING, CLEARING, AND PLANTING ON THE

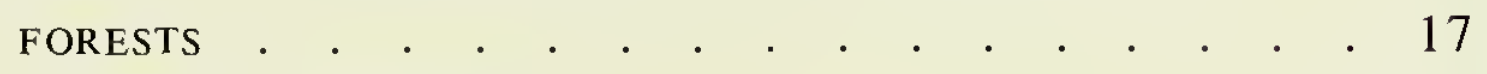

CHANGES IN THE MEADOWS . . . . . . . . . . . 21

INTRODUCTION OF PLANTS . . . . . . . . . . . . . 25

RE-ESTABLISHMENT OF PLANTS ON DENUDED AREAS . . . . 26

WILDLIFE INFLUENCES • • . • • • • • • • . . . 28

INFLUENCE OF FLOODS AND ROCKSLIDES . . . . . . . 30

INFLUENCE OF VISITORS . . . . . . . . . . . . . 31

DISCUSSION . . . . . . . . . . . . . . . . . . 33

ACKNOWLEDGMENTS . . . . . . . . . . . . . . . 34

LITERATURE CITED . . . . . . . . . . . . . . 35

BIBLIOGRAPHY . . . . . . . . . . . . . . 37

APPENDIX . . . . . . . . . . . . . . . . 38

The Authors / Robert P. Gibbens is Assistant Specialist, School of Forestry, University of California, Berkeley; HAROLD F. HEADY is Professor of Forestry, School of Forestry, University of California, Berkeley.

J U L Y, 1964

This manual is one of a series published by the University of California Division of Agricultural Sciences and is sold for a charge which is based upon returning only a portion of the production cost. By this means it is possible to make available publications which, due to relatively high cost of production, or limited audience, would otherwise be beyond

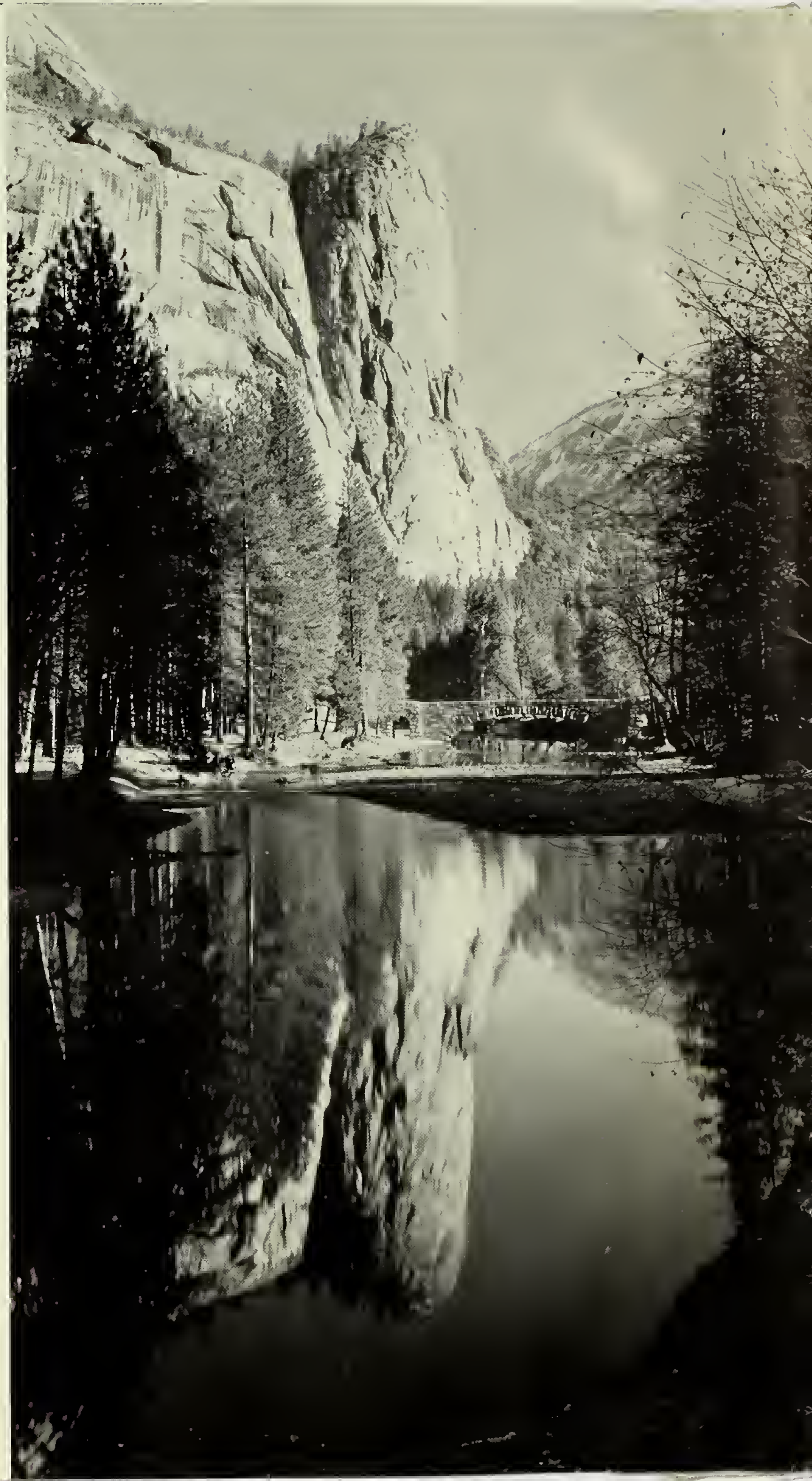




\section{Introduction}

RECREATION in wildland areas is a major land use which is rapidly gaining in extent and intensity. Because of this, recreationists may possibly destroy their favorite wildland areas through sheer numbers and overuse. To preserve the recreational values of such areas their natural conditions must be understood and the changes caused by recreational use determined. Because its spectacular scenery has attracted so many visitors, Yosemite Valley has a well-documented history as a recreation area, and thus offers a unique opportunity for study of changes caused by recreationists.

Yosemite Valley is young geologically, although its age is great when compared with its short historical period. Man is a newcomer to the Valley, but in his short tenure he has exerted a great influence on its vegetation. Aboriginal man manipulated the Valley's vegetation to supply his basic needs, but modern man has been more of an exploiter. Fortunately, exploitation of the Valley was tempered by the early realization that its scenic values were unique and should be preserved.

Since 1864, when Yosemite Valley was set aside as a public trust, two objectives have guided its management: perpetuating natural conditions for continued enjoyment and, secondly, encouraging public use. But attempts to attain both objectives inevitably result in conflict as more and more disturbance of natural conditions is caused by the ever-increasing influx of visitors. How much disturbance of natural conditions has occurred? How much can be allowed? Before these questions can be answered, an understanding of natural and man-caused vegetational changes in the valley is needed.

Non-biological forces-such as rainfall, wind, fire, and climatefluctuate, and thus influence biological communities. Additionally, the development of a biological community often so alters its own conditions that some other community replaces it. This constant interplay of physical and biological forces unhindered by man also results in continual, though often unrecognized, changes of the natural state. Man can, and often does, cause additional change, as did the Indians inhabiting Yosemite Valley before 1851. Their influence on the vegetation is recognized but not examined in detail in these pages, as major emphasis is given to man's influence on the natural scene since 1851 .

The objectives of this study, which was conducted in 1961, were (1) to define natural conditions existing in the Valley in 1851, and (2) to determine the role of historical events in changes which have led to the Valley's present patterns of forest and meadow. With such information, more accurate predictions of landscape-management results are possible, and as a result the biologist is better prepared to furnish his share of the information needed to strike a balance between the natural scene and the vegetational changes caused by recreational use of the Valley. 


\section{Events affecting the vegetation}

Chronologies of historical events in Yosemite Valley have been prepared by Russell (1959) and by Paden and Schlichtmann (1955). Accounts of the Valley's early history were also recorded by Hutchings (1886) and Bunnell (1911). The year 1851 marks the first recorded entry of modern man into the Valley. Prior to this the Valley had been part of the territory occupied by the Awanichi, a small tribe of Miwok Indians. This tribe left the Valley in the late 1700 's or early 1800 's, but a Miwok group re-entered the Valley at least one generation before 1851. Considerable evidence indicates that the Indians used fire and hand-eradication methods to control brush and tree growth in the Valley (Ernst, 1943; Reynolds, 1959).

By 1854 the tribe was drastically reduced in numbers and their culture, as a major influence on the vegetation, had largely ended. This disruption of the Indian culture was, indirectly, the first influence of white man on the vegetation. If we credit the Indians with slowing down the ecological succession of plants in the Valley, the period of change thus began in about 1854. Thomas Ayres made the first published sketches of the Valley in 1855 and these, plus written descriptions, brought publicity that greatly accelerated the Valley's occupation.

2
Events now happened swiftly. The first trail to the Valley was completed in 1856. The first permanent structure, the "Lower Hotel," was erected in 1856 near the base of Sentinel Rock, and the "Upper Hotel" was built near the present Sentinel Bridge in 1858; these sites were focal points of activity for many years. The first settler, James C. Lamon, located a preemption claim in the upper end of the Valley in 1859 , built a $\log$ cabin, planted an orchard, and cultivated a garden. With the arrival of J. M. Hutchings and his family in 1864 , year-round occupation was firmly established. Hutchings also planted an orchard and cultivated a garden; hay was harvested, fields were plowed to provide grain, and buildings were constructed. Thus, some of the meadowlands and woodlands began to be affected.

The year 1864 saw Yosemite Valley and the Mariposa Big Tree Grove granted to the state of California as a public trust. A

Figure 1A. Yosemite Valley from Glacier Point, 1866. showing the Hutchings home, corral, and several split-rail fences. Photograph by C. E. Wathins.

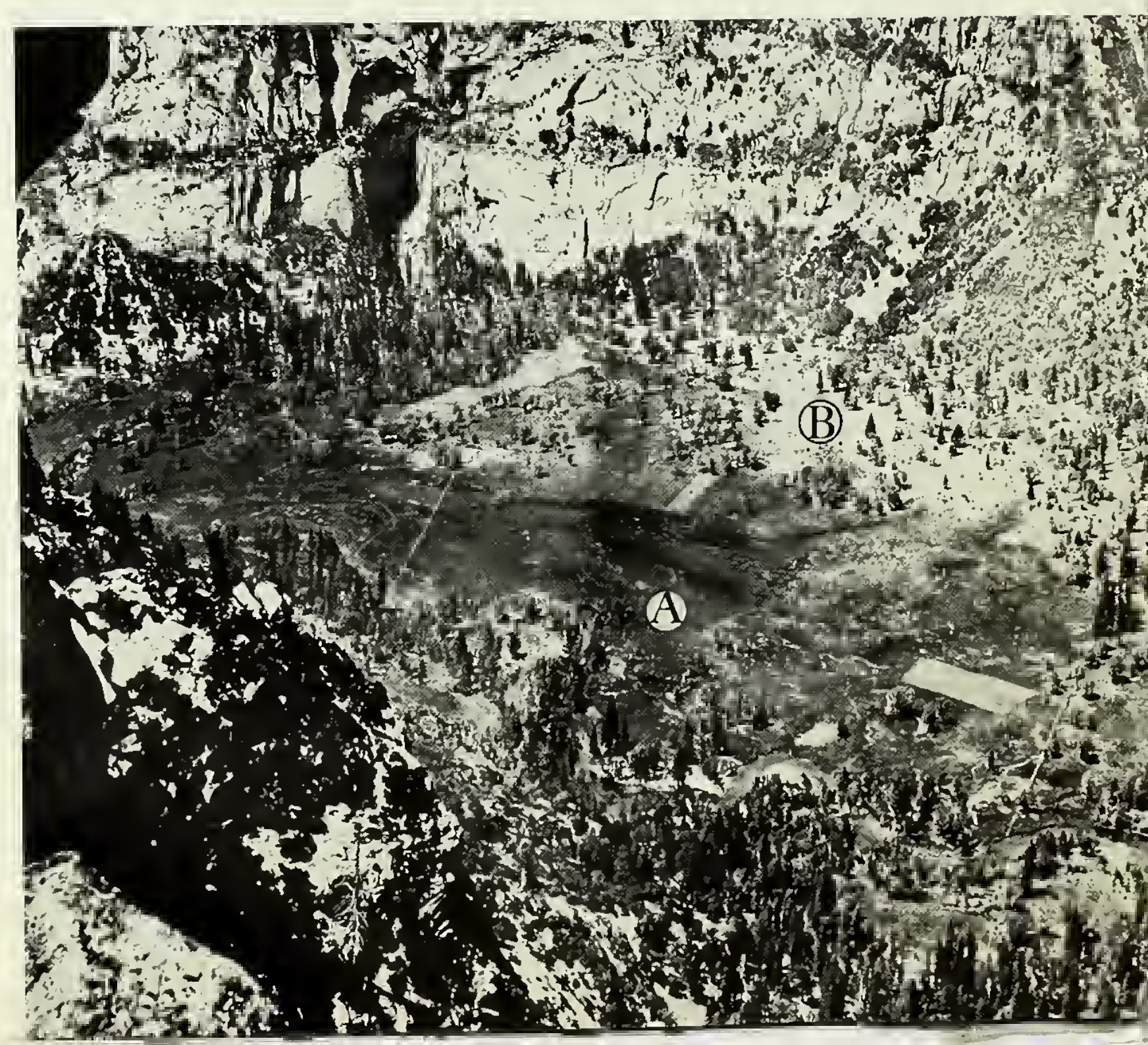


survey to establish the boundaries of the grant, which extended back from the cliffs an average distance of one mile, was made in the same year. Commissioners to manage the grant were organized in 1866, when legal acceptance of the grant by the State was completed.

Between 1870 and 1880 tourist facilities rapidly expanded and trails were constructed to Glacier Point, Nevada Falls, and other areas. In 1874 the Coulterville and Big Oak Flat stage roads made entry to the Valley. During the 23 years when access was by horse trail only, over 12,000 persons visited the Valley and by 1878 the influx of visitors necessitated the establishment of the first public campground. The Commissioners did not attain full control of the Valley until 1875 when claims of the early settlers were finally extinguished. However, leases were still granted and few land-use restrictions were placed on lessees.

Figure IB. View from Glacier Point, 1943. National Park Service photograph

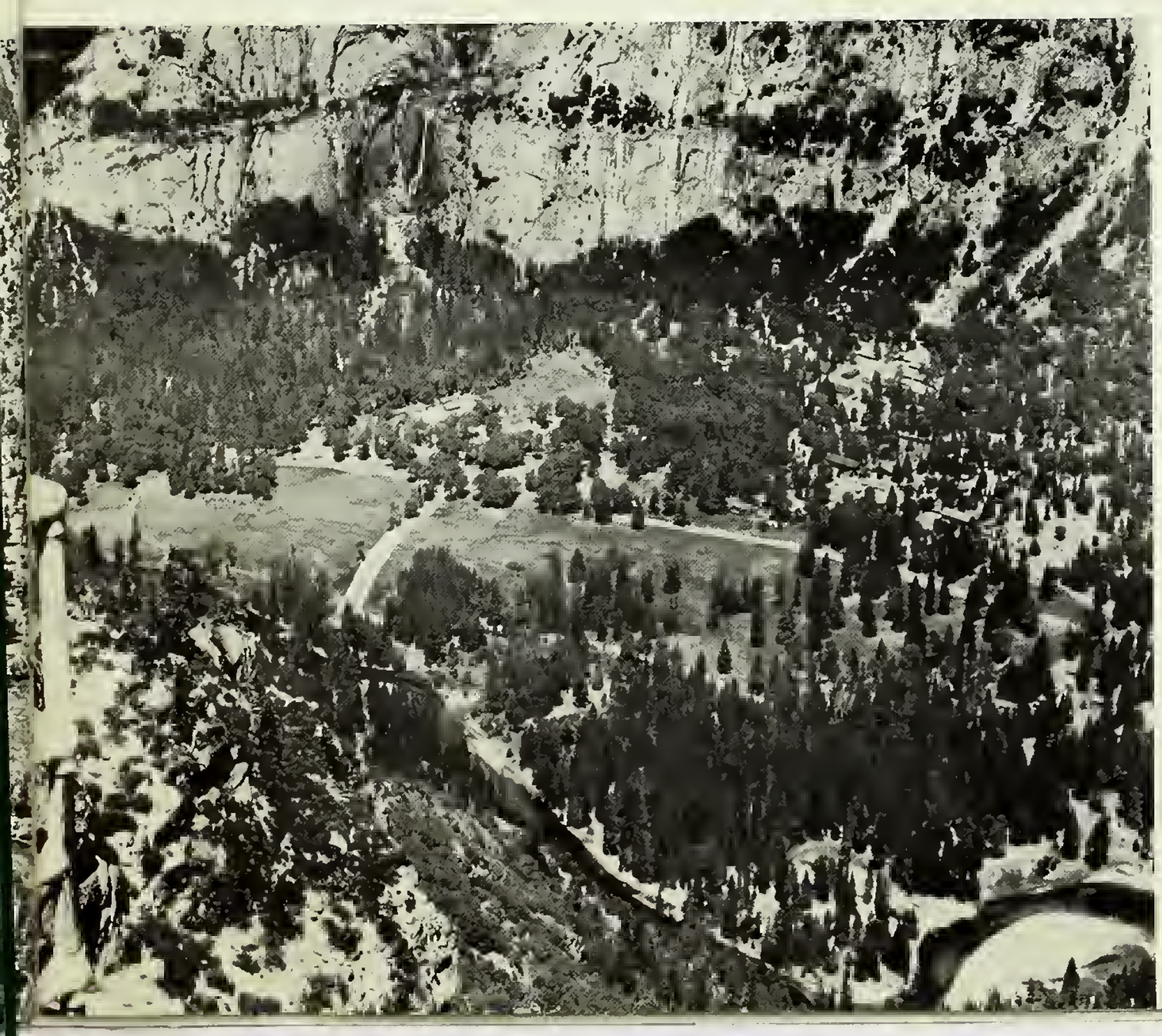

The following statements, from the 1880 Commissioners' Report, indicate that conditions in the Valley were causing concern:

1. Most of the available land is under lease for pasture and garden purposes.

2. The enclosed fields are being invaded by willows, wild roses, and other growth, to the damage of their value and of the beauty of the Valley.

3. The upper portion of the Valley, which has been set apart for the convenience of campers, is largely overgrown with willows and young pines. The views are obstructed, the pasturage destroyed, and the appearance injurcd.

4. There is no practicable and unobstructed carriage road around the Valley, near the base of the cliffs. At present all who attempt to make the circuit of the floor of the Valley, must pass through gates and fields, lose some of the finest views, and be subjected to annoyance and loss of time.

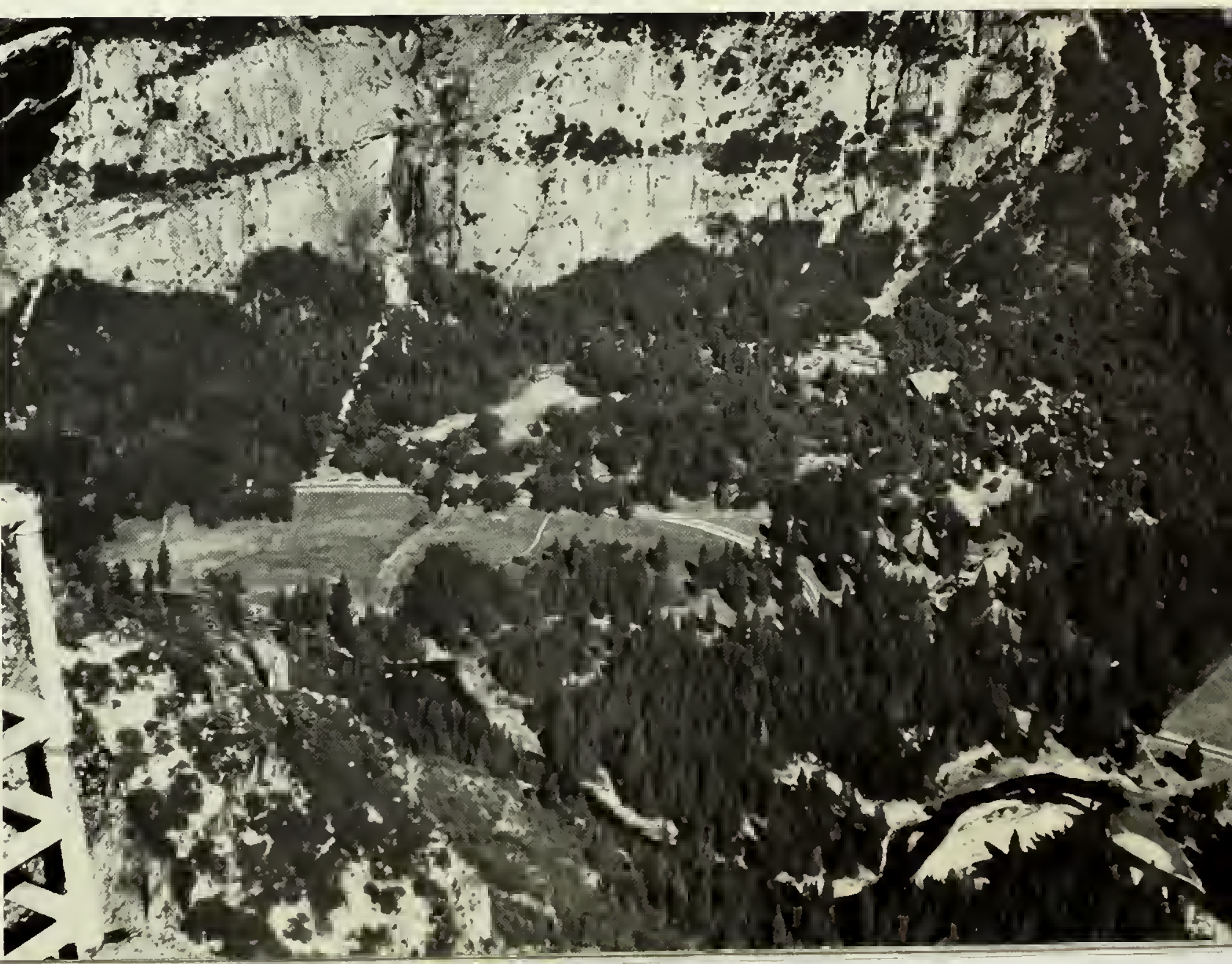


improvement activities reached unprecedented levels when abundant labor was made available during the 1930's: ditches were constructed, campgrounds delimited, screening trees planted, dead trees removed, thickets thinned, insect-infested trees cut and burned, young trees cut from meadows, meadows drained for mosquito control, river and creek channels cleared, banks sloped and covered to halt erosion, low areas filled, ground squirrels eradicated, and deer trapped and removed. According to the Superintendent's Monthly Reports for the 1930's, there were few areas in the Valley which did not receive a face-lifting of some sort. These landscaping activities ended with the start of World War II.

After the war, activities affecting vegetation were largely confined to maintenance-type work: thistle control in the meadows, removal of dead and dangerous trees, limited vista-clearing, relocation of the Old Village and other structures. In post-war years, the dominant factor affecting vegetation has been the increase in the number of visitors, now (1963) numbering over 1,200,000 persons yearly.

\section{Vegetation at the time of discovery}

UNFORTUNATELY, we have only meager descriptions of the vegetation of the Valley at the time of its discovery by white man. Plants and vegetation were weak rivals for attention compared with cliffs

Figure 3A. Lower end of Yosemite Valley in 1866 from Old Inspiration Point. The large open area in the lower left part of picture is Bridalveil Meadow. Note the open

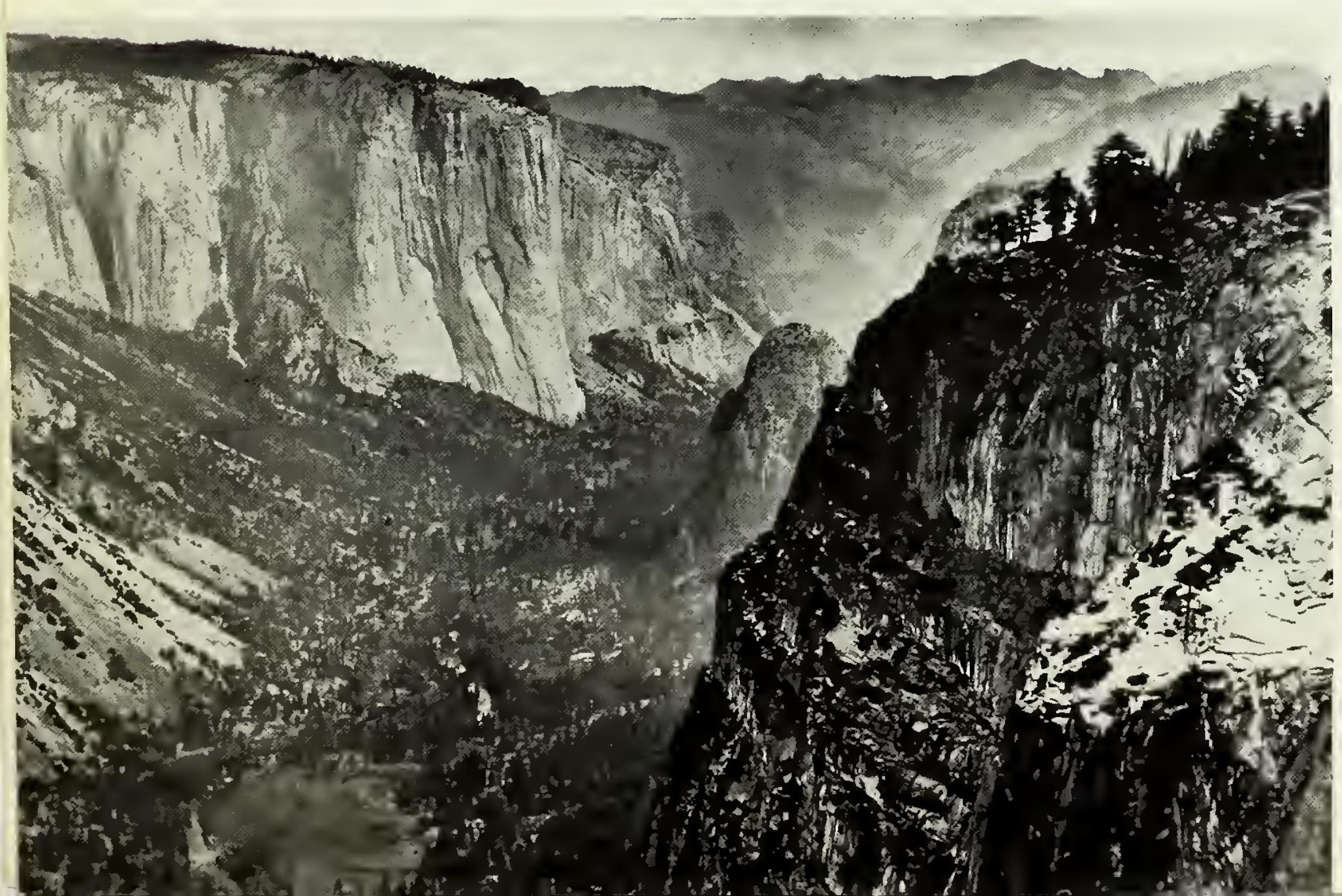

Figure 3B. View from Old Inspiration Point, 1961. The old Big Oak Flat road can be seen on the talus slope north of the river. Photograph by R. P. Gibbens.

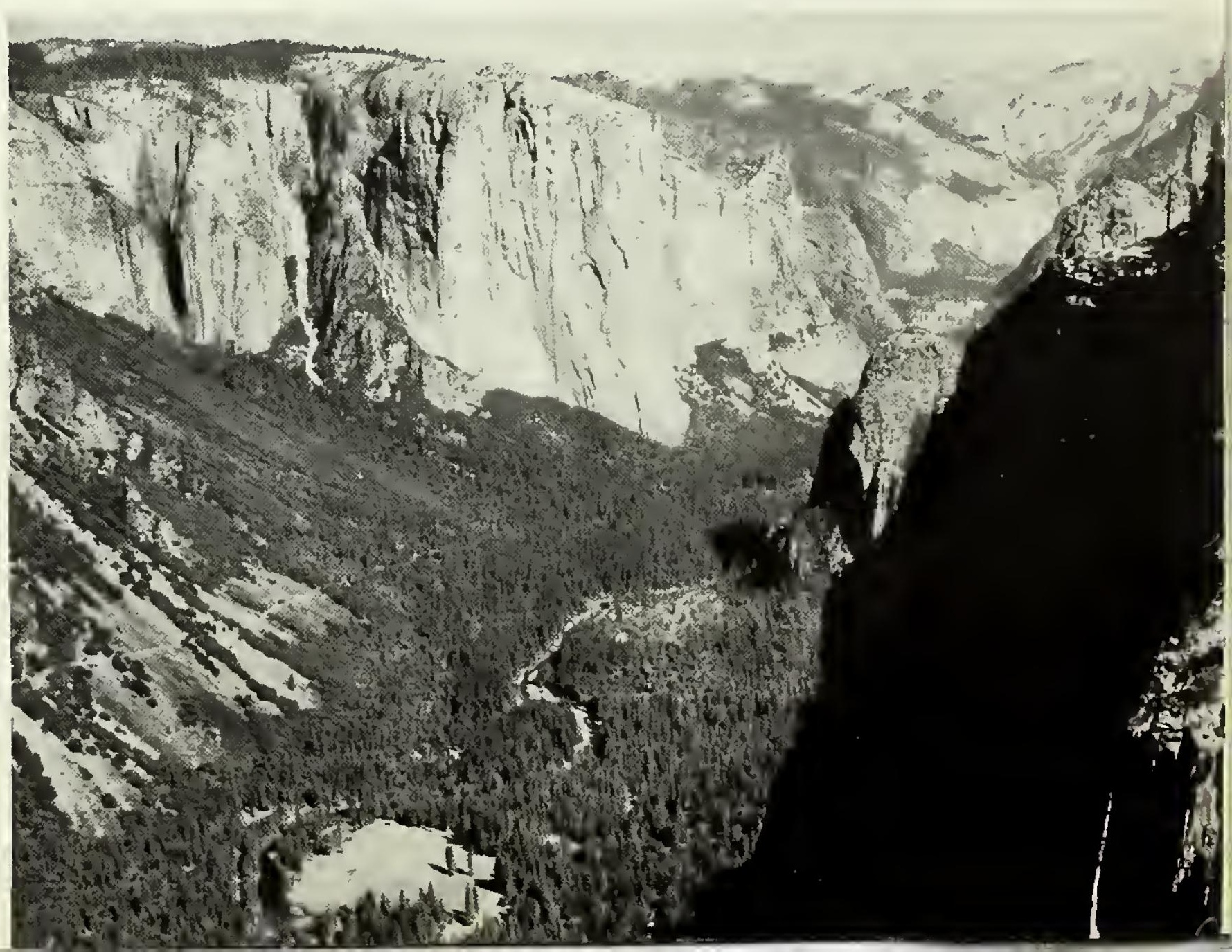


and waterfalls when early descriptions were written, and this is true today. Even such naturalists as John Muir, who spent much time in Yosemite and wrote of it extensively, recorded little specific information on its flora; statements like "Verdant banks of new leaves, and groves of half-open ferns, and thick settlements of confident flowers ..." (Muir, 1915) are of little scientific value. Fortunately, a few sources containing other observations were found. A brief comment on vegetation by a member of the Mariposa Battalion which entered the Valley in 1851 was included in the Commissioners' report for 1889-1890:

The valley at the time of discovery presented the appearance of a well kept park... There was then little undergrowth in the park-like valley, and a half day's work in lopping off branches along the course enabled us to speed our horses uninterrupted through the groves.

Galen Clark, in a letter to the Commissioners dated August 30 , 1894, said, in part:

\begin{abstract}
My first visit to Yoscmite was in the summer of 1855. At that time there was no undergrowth of young trces to obstruct clear open views in any part of the valley from one side of the Merced River across to the basc of the opposite wall. The area of clear open meadow ground, with abundance of luxuriant native grasses and flowcring plants, was at lcast four times as large as at the prescnt time.
\end{abstract}

Sketches by Thomas Ayres, the artist who visited the Valley with J. M. Hutchings in 1855 , also suggest that trees were widely spaced on the Valley floor.

In 1866 the State Geographical Survey party under direction of J. D. Whitney made a detailed geographical and geological survey of the Yosemite Valley region. This survey, published in 1868 as The Yosemite Book, contains the first detailed descriptions of vegetation. It seems unlikely that extensive changes had occurred during the 15 years since 1851. The few Indians occasionally inhabiting the Valley continued the burning which was credited with maintaining the park-like appearance of the Vallcy. Baxley
(1865) described his arrival at the Valley in the fall of 1861 as follows:

A fire-glow in the distance, and then the wavy line of burning grass, gave notice that the Indians were in the valley clearing the ground, the more readily to obtain their winter supply of acorns and wild sweet potatoe [sic] root-'huckhau.'

Whitney (1868) included a lengthy description of the vegetation in 1866 (currently-used names are in brackets):

Along the banks of the river and over the adjacent rather swampy meadows, we find a somewhat varied vegetation, according to the locality, the narrow portions of the Valley differing considerably from the broader ones. In the former, near the falls, there is a dense growth of alder (Alnus viridis), $[A$. rhombifolia $\ldots$. . associated with this are small trees of Rliamnus Menziesii, [??]... A A few willows [Salix spp.], the Douglas spruce (A bies Douglasii), [Douglas-fir, Pseudotsuga menziesii] and, in the upper part of the Valley, an occasional sugar pine [Pinus lambertiana], are also found in this position. Where the Valley widens out, and the river banks become lower, so that sloughs and swamps are formed, the Balm of Gilead popular (Popullus balsamifera) [black cottonwood, P. trichocarpa] comes in; this is a common tree in the Valley,... with this occur large willows and abundance of the Douglas spruce, and also the Azalea occidentalis,.... The meadows are swampy, with a deep peaty soil; their vegetation consists chiefly of carices or sedges and a few coarse grasses....

The sandy region of the Valley proper forms a connecting strip along the edge of the rocky talus, on both sides of the river. ... This is peculiarly the arboriferous belt of the Valley. and various portions of its area exhibit different characters of vegetation to correspond with the differences of soil. On the drier and looser portions, the pitch (or ycllow) pine ( $P$. ponderosa) and the bastard cedar [incense-cedar] (Libocedrus decurrens) are the most abundant and characteristic trees; both these species occur of considerable sizc and of fine proportions, the pines being usually from 125 to 150 feet high. Below the Bridal Veil Fall, near the debris, the fir (Picea grandis) [white fir, Abies concolor], a noble tree, comes in; near the swampy land, the black oak (Q. Sonomensis) [Quercus kelloggii] is 
abundant. The sandy regions also bears a great number and variety of shrubs and undergrowth;... .

The most characteristic tree of the debris piles is, perhaps, the mountain live-oak [canyon oak] ( $Q$. chrysolepis, Liebm.)

The spectacular scenery attracted early photographers, and their photographs provide the best means of determining vegetational changes. The first pictures were taken in 1859 by C. L. Weed, who took additional photographs in 1863. Examination of some of these show few changes between the above dates and 1866, when C. E. Watkins took an extensive series. The Watkins photographs (figs. 1A, 2A, and 3A) depict original conditions on the Valley floor.

Although white man had altered conditions to some extent by 1866 it seems reasonable that the vegetation was not greatly different from that of 1851 . Whitney's description fits the conditions shown by the photographs-for example, the "arboriferous belt" is plainly visible in figures $1 \mathrm{~A}$ and $2 \mathrm{~A}$.

Whitney (1868) also gives the extent of vegetational types. "There are, altogether 1,141 acres of land in the Valley proper, of which 745 are meadow, and the remainder, a sandy soil, a little more elevated, partly covered with a sparse growth of forest trees and partly with pertinacious ferns." The acreage figures were evidently based on a stylized plat prepared by a member of the survey party (fig. 4). Whitney evidently restricted his definition of meadows and "land in the Valley proper" to low-lying areas which were periodically flooded. Based on planimeter readings from the 1961 U. S. Geological Survey map of Yosemite Valley there are, from Pohono Bridge to the eastern end of the Valley, over 2,200 acres enclosed by the 4,000 foot contour line which roughly coincides with the base of the talus slopes. Vegetation in 1866 thus seems to have consisted of extensive wet meadows bordering the river and of open forests along the sides of the Valley.

In 1851 the tree population in the Valley was composed of two distinct age groups. One group consisted of old-growth stands, primarily black oak and scattered individuals of ponderosa pine, incense-cedar, white fir, and Douglas-fir; counts of growth rings indicate the age of this group to be largely in excess of 250 years. Reynolds (1959), besides noting the old-growth stands, observed a "stand of intermediate age" consisting of ponderosa pine and incense-cedar. On the basis of growth-ring counts, he placed the age of this group of trees at about 150 years, with the date of origin being 1800 plus or minus 10 years. According to Bunnell (1911), the Indians fled the Valley temporarily because of disease, and Reynolds speculates that the period when the Valley was empty might well have been about the year 1800; the trees were able to become established then because the Indians were not present to carry out their usual practice of burning.

The presence of the other group, intermediate-aged stands, is significant because it indicates that a trend toward the development of a forest cover existed before 1851. One wonders what preceded the old-growth stands? Plant succession only to a black oak stage in the 10,000 years since the filling of ancient Lake Yosemite seems highly unlikely. Plant succession probably did not pass through marsh, bog, and meadow stages because the lake was filled by delta formation which would allow colonization by trees on a well-drained substrata. The hypothesis that woody plants appeared at an early date is supported by Matthes (1930):

It is probable, . . , that like the [present] deltas at Merced Lake and Washburn Lake, the delta at the head of Lake Yosemite was largely covered with vegetation. Its more stable portions bore forest trees, and its shore was fringed with willows. That the climatic conditions permitted vegetation thus to establish itself can scarcely be doubted, for there are indications in various parts of the Sierra Nevada that even during glacial time extensive forests of pine and sequoia flourished on its lower slope and well up on the ridges between the canyons.

Evidence of former forests in Yosemite is found in old soil profiles in the talus slopes (Matthes, 1930). If forests developed enough 


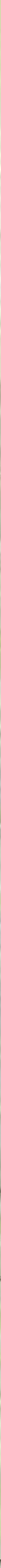




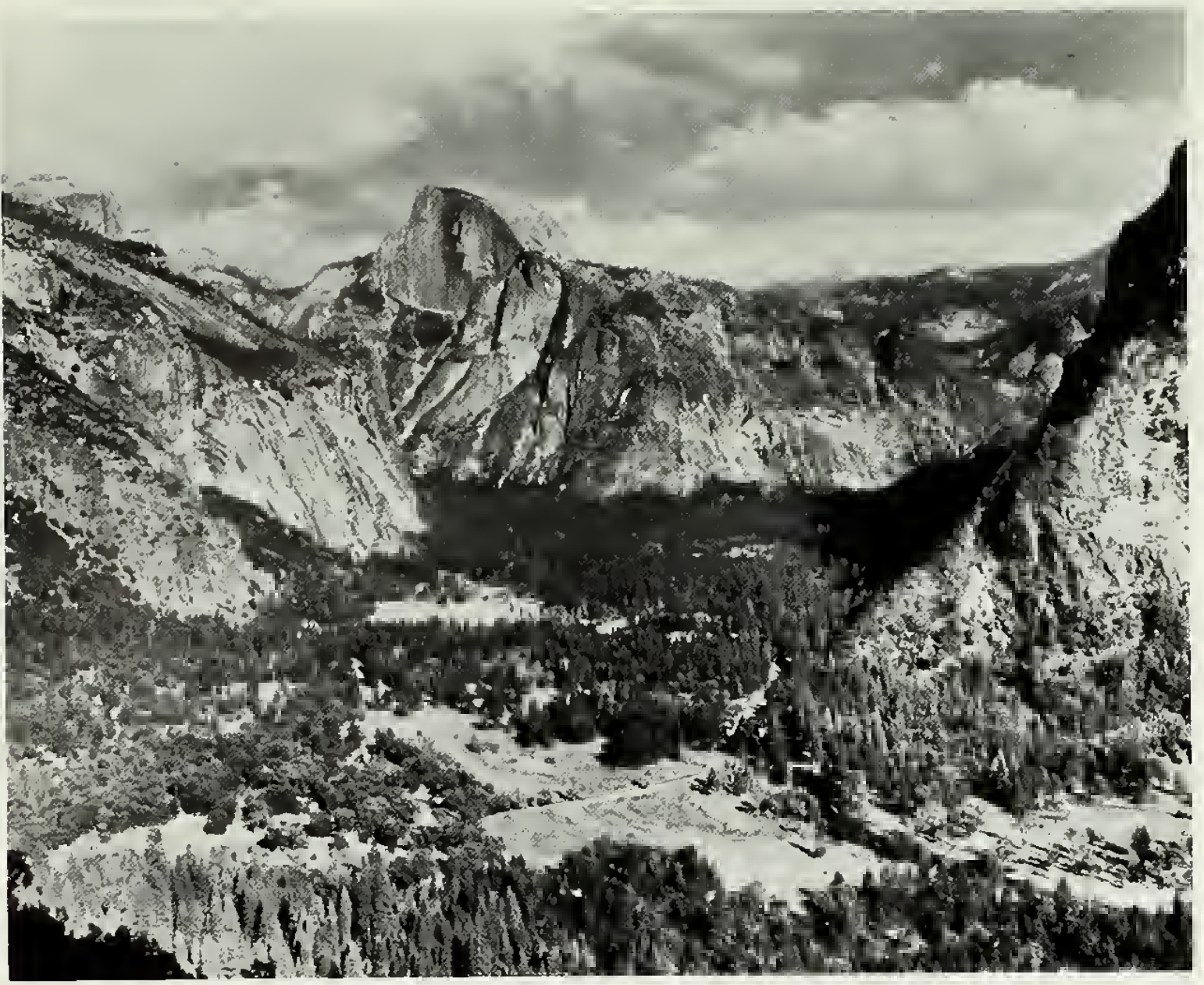

Figure 6B. View from Columbia Point, 1943. National Park Service photograph.

stands of white fir are found in certain areas, and willows and wild roses (Rosa spp.) are listed as invaders of open fields in the Commissioners' Report for 1880. Galen Clark (1894) noted that young willows and cottonwoods were becoming so thick on the meadows that little clear ground was left. Today, only a few of these plants survive.

The rapid growth of conifers has greatly changed the appearance of extensive woodland areas formerly dominated by black oak (see

Left, Figure 6A. View of upper end of Yosemite Valley from Columbia Point, 1899. Pre-1851 conifers are plainly visible above the stands of black oak and young trees. Photograph by H. G. Peabody.

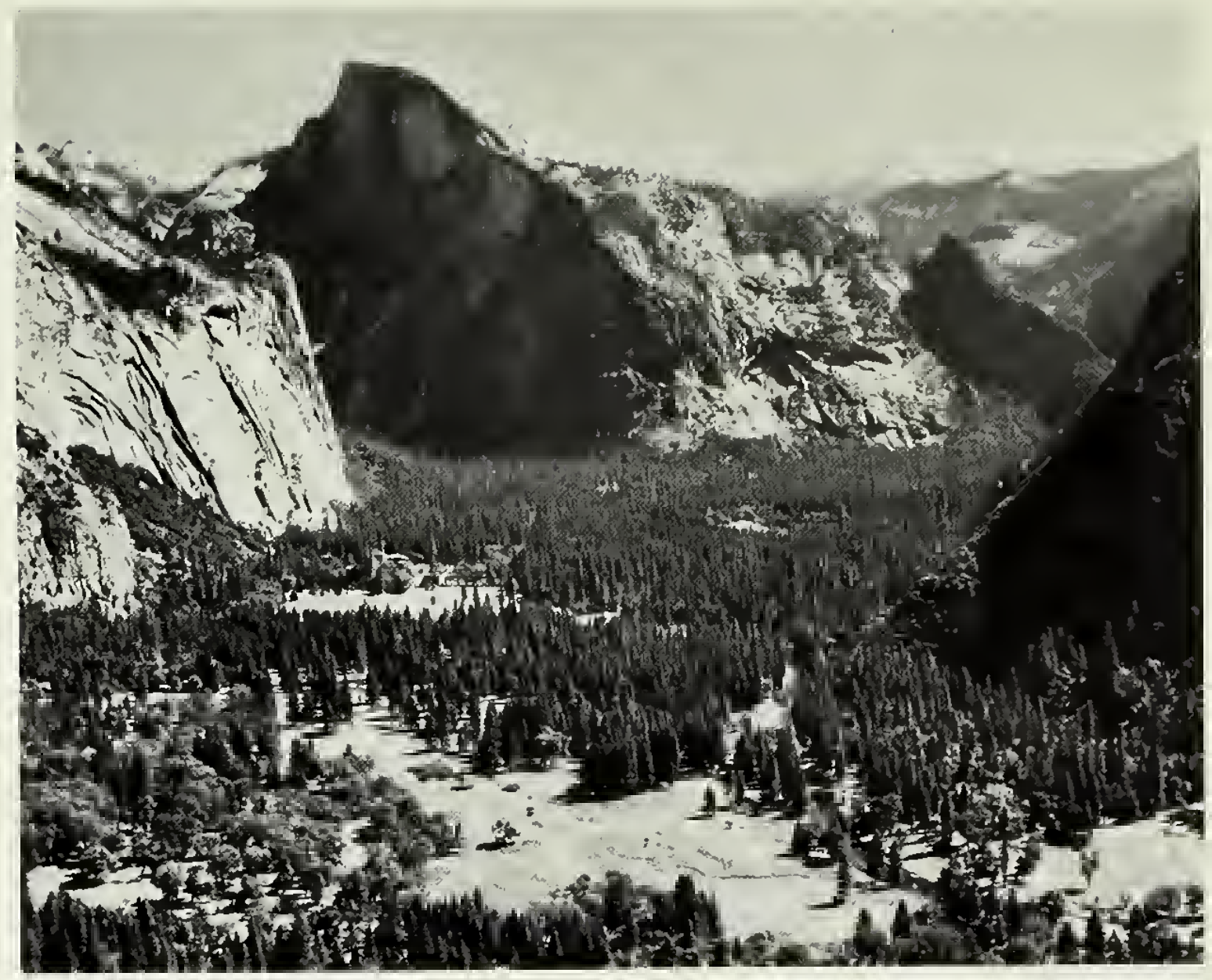

Figure 6C. View from Columbia Point, 1961. Photograph by R. P. Gibbens.

all photographs in figure 8 ). Black oaks are still present, but they have been overtopped by conifers and are no longer dominant. Ponderosa pine and incense-cedar are now the most abundant trees and dominate most of the forested areas on the Valley floor (appendix tables 1 and 2). Small areas are dominated by white fir, Douglasfir, black oak, black cottonwood, and alder. Canyon oak is dominant on most of the talus slopes.

In the forest stands outside the Valley's campgrounds the increase in tree density has been a continuing process, and there is often a continuous range of tree ages and sizes from seedlings to the pre1851 trees (figs. 9, 10). Growth of the understory trees is slow, as can be seen by the ages of trees with a small diameter (appendix fig. 1). Recent tree establishment has not been confined to forest 
Figure 7A. Right, top. The Black Spring area, 1866. Photograph by C. E. Watkins.

Figure 7B. Right, center. The Black Spring area, 1943. A small rock has rolled against the larger one since the 1866 photograph was taken. National Park Service photograph.

Figure 7C. Right, bottom. The Black Spring area, 1961. Tree in left foreground is about 73 years old; small incense-cedars in center are 65 to 70 years old. Flowering incense-cedars in center are 65 to 70 years old. Flowering
dogwood has become established since 1943. Photograph by H. F. Heady.

stands, however, as young trees are found on meadows and other open areas (figs. 11, 12).

The development of a dense tree canopy has created conditions favorable for the establishment of shade-loving plants within the forest. The high shade tolerance of incense-cedar accounts for its abundance as an understory in dense stands. Young trees and seedlings of two other shade-tolerant species, white fir and Douglas-fir, have appeared in the dense stands of ponderosa pine and incensecedar. It is possible that white fir will in time become a co-dominant with ponderosa pine and incense-cedar. Plants other than trees now occupy sites formerly unfavorable for them-flowering dogwood (Cornus nuttallii), for example, has become established at Black Spring since 1943 (fig. 7C).

Sampling of several forested sites showed that the herbaceous understory is varied, both in species and density (appendix table 3 ). Although the tree cover is often essentially the same, there is a great deal of difference in understory plants on wet and dry sites (figs. 13, 14).

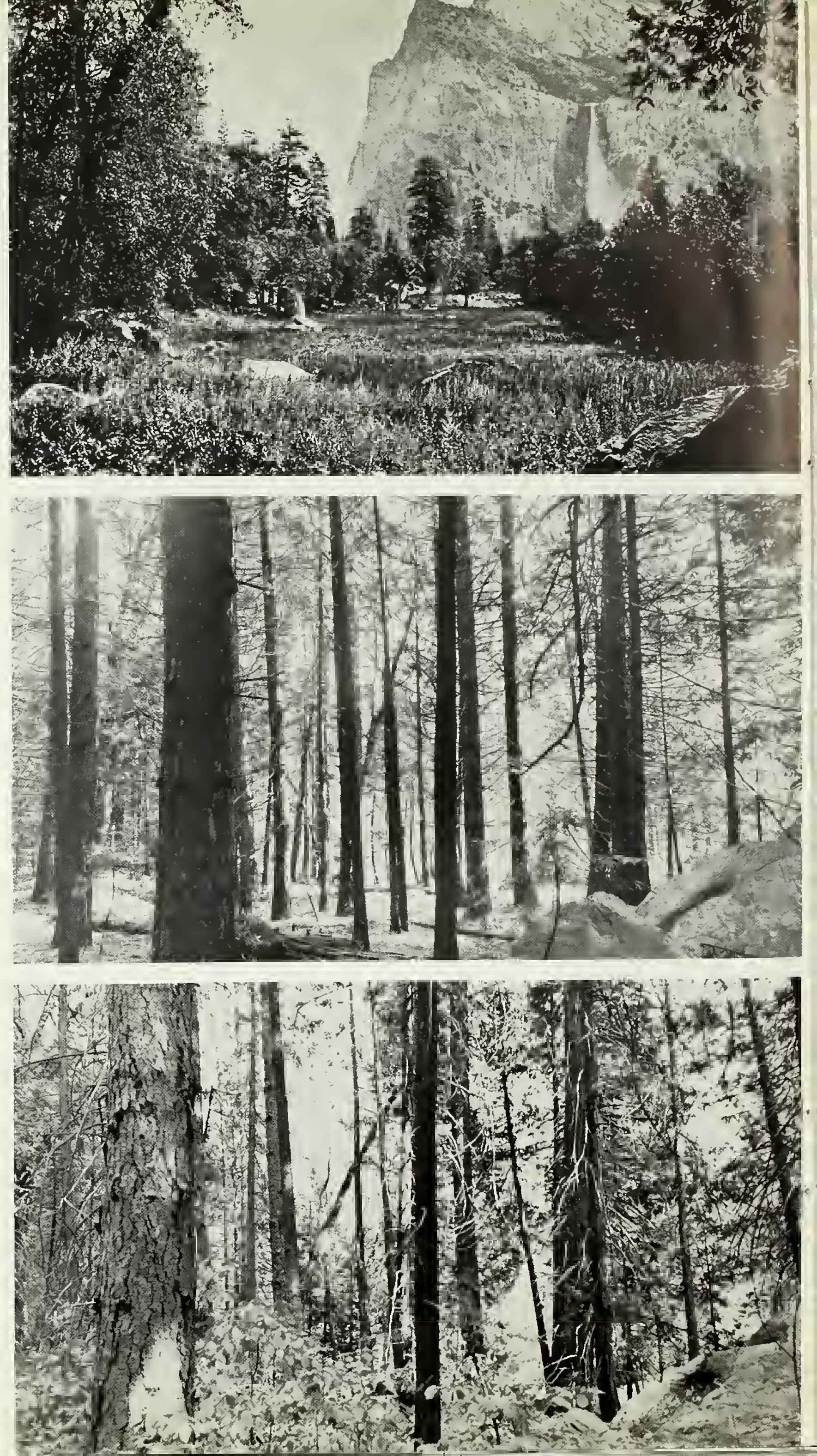




\section{Causes of tree increase}

THE INCREASE in woody plants was often attributed to the ceasing of burning by the Indians, but another hypothesis to explain the increase was postulated by W. H. Hall after his visit to the Valley in 1881 (Hall, 1882):

The use of the valley itself by the constant travel and the grazing of animals upon it, is beginning to tell upon the character and extent of its vegetable productions. The finer forage grasses are being thinned out; the coarser and more robust or hardy grasses and wecds, able to withstand the trampling and cropping, are taking their places; and the area of meadow is decreasing, while young thickets of forest or shrub growth are springing up instcad. ... The cause is alleged to be the abolition of the old practice of burning off the thickets, which practice formerly made new clearings almost every year for grass growth. Doubtless this clearing had its effect in this way, but another cause, and perhaps a more potent one, is to be found in the continued cropping of the grass and trampling of the ground by horses. The finer grasses are cropped off, pulled up, trampled under foot into soft meadow ground, while coarser growths are avoided by browsing animals and permitted to flourish. The soil and the subsoil of the meadows is becoming compacted, and percolation of watcrs therein is arrested, so that they dry out earlier each year; the change in character of thcir forage vegctation results, and the thicket growths encroach upon their borders.
Hall was not the only person to note the impact of grazing on vegetation during this period. The Commissioners' Report for 18851886 states in part:

During the season now closing - with its list of visitors largely in excess of former years-the utmost resources of the valley were drawn upon and exhausted for pasturage. Any increase of demand must be met by a timely increase of meadow land area. and the Commission has no choice but to appeal to the State on this behalf. The truth is that, under the strain of over-pasturage, the best meadow lands are being injured, while all of them show narrowing lines from the encroachment of brambles and thickets of young pines, willows, and cottonwoods, and some of them are so entirely overgrown as to have passed out of a pasturage classification into that of woodland.

It seems safe to assume that overgrazing was a factor in 1870 when trees began to increase in number. In 1868 there were only 623 visitors, but in 1869 visitors numbered 1,122 , and this increase meant that the meadows, already grazed by residents' livestock, were grazed by many additional animals. 1870 is only the approximate beginning of widespread increase in trees; many became established in the late 1870's and early 1880's when grazing was severe.

Hall (1882) made an accurate analysis of grazing factors which contributed to the spread of trees: Heavy grazing allows seedlings to become established by reducing the competition from sedges, grasses, and broad-leaved plants. Trampling creates drier conditions by compacting the soil and, in very wet areas, by forming a rough, ridged surface which increases evaporation and drying. Exposure of mineral soil provides an excellent seedbed. With conditions favoring seedling establishment, the absence of fire allows trees and shrubs to develop. Even if occasional fires do occur their effectiveness as a killing agent is greatly lessened because herbaceous fuel is scarce.

There is no evidence that the early spread of trees in meadows was facilitated by a lowering of the water table, and it is unlikely that deposition raised land levels significantly between 1851 and 1870. Blasting of the rocks in the river channel at Bridalveil in 


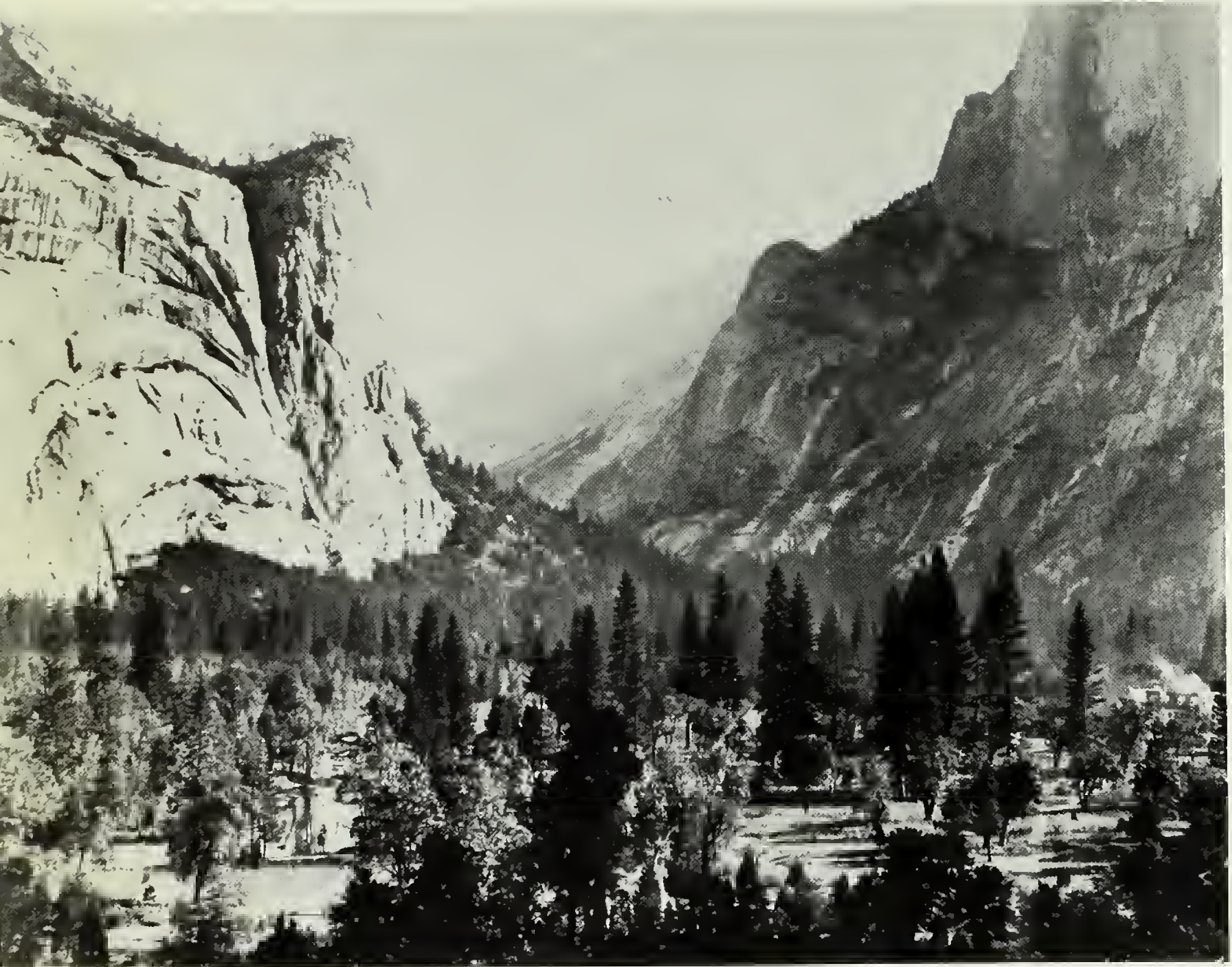

Figure 8A. The upper end of Yosemite Valley as it appeared between 1887 and 1896; the Stoneman House is visible on right. Young conifers are visible among the black oaks. Photograph by George Fiske; exact date unknown.

1879 was the first recorded event which might have caused an appreciable lowering of the water table, but this was 10 years after the start of tree invasion. Ernst (1961) has suggested the possibility of a lowering of the water table by natural processes coincident with early settlement of the Valley, but this cannot be substantiated. Evidence already presented indicates that tree inva-

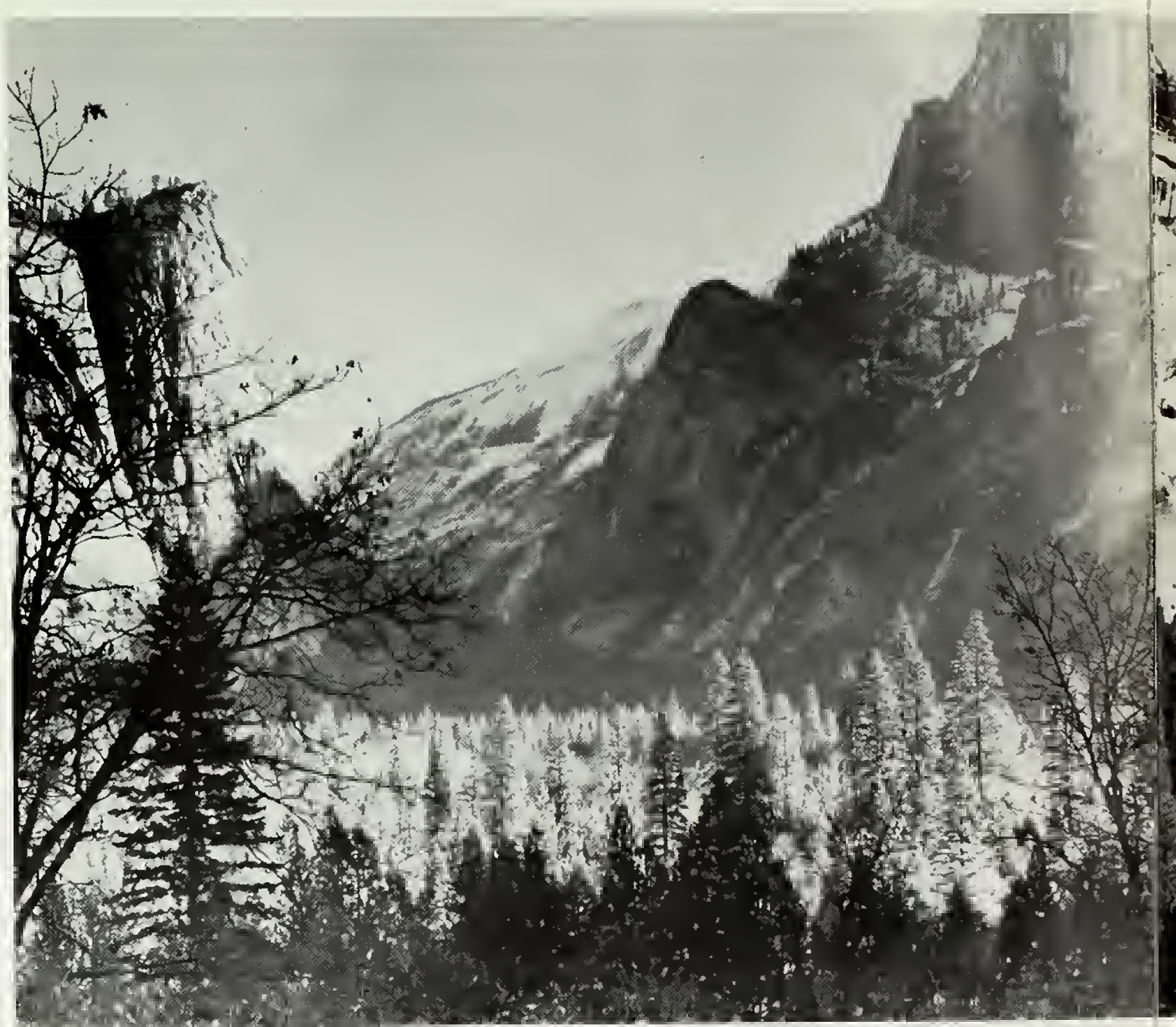

Figure 8B. Upper end of Yosemite Valley, 1943. The black oaks have been overtopped by ponderosa pine and incense-cedar. National Park Service photograph.

sion occurred in wet habitats; in addition, willows and cottonwoods (adapted to very wet conditions) were not abundant when white man arrived but increased after his arrival. Only the marshes appear to be too wet for establishment of a coniferous cover, and no soil habitat in the Valley is too dry.

Since trees have become established in meadow areas after grazing 


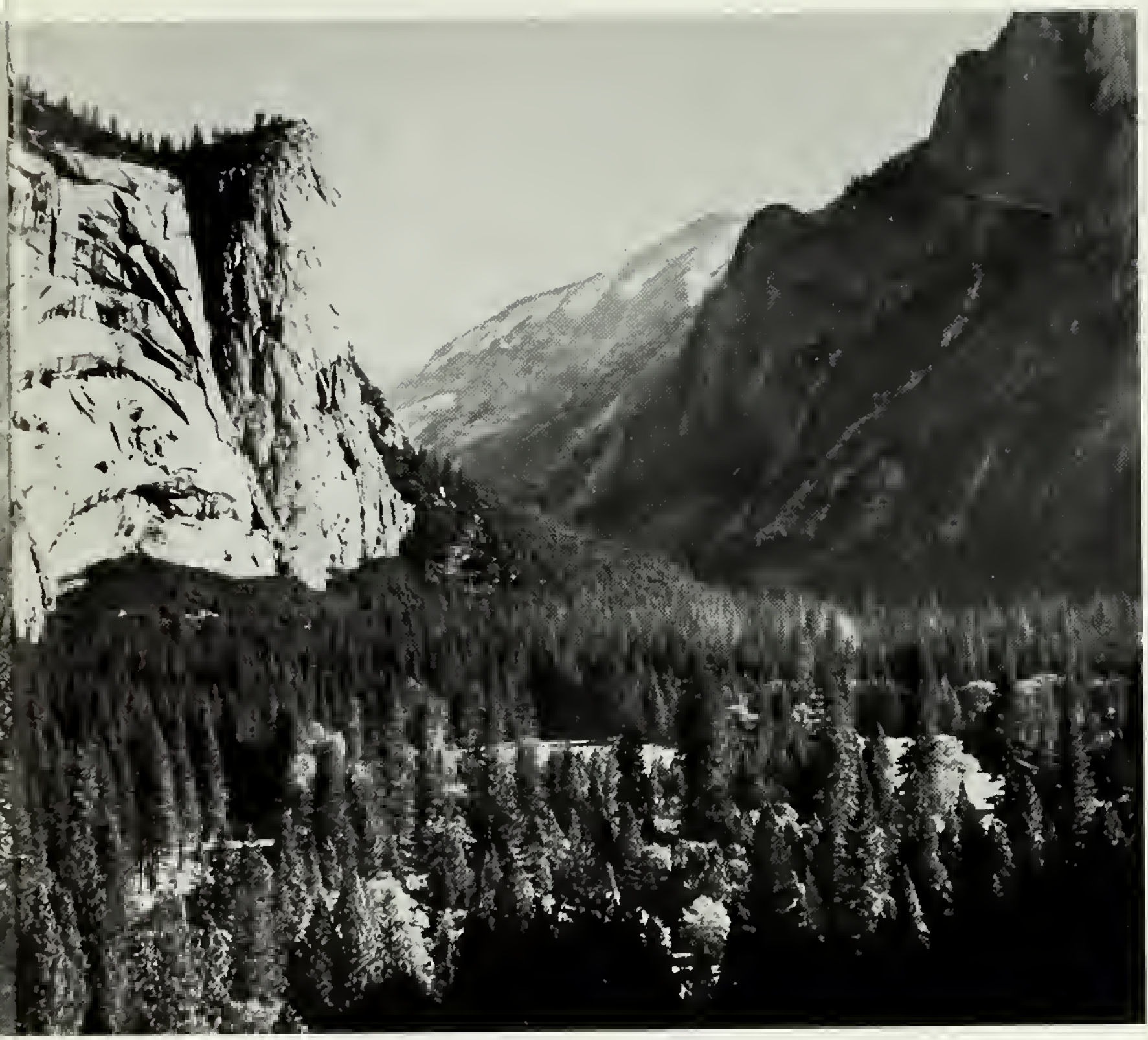

Figure $8 \mathrm{C}$. View of same area in figures $8 \mathrm{~A}$ and $8 \mathrm{~B}$ but taken from a ledge above the original point to avoid screening trees. Photograph by R. P. Gibbens, 1961.

ceased (fig. 11), it seems most probable that fire was the major factor in suppressing them before 1851. Heavy grazing, which coincided with the first widespread establishment of trees, was more an accelerating than an initiating factor. The drying influence of trees, and possible lowering of the water table, did not influence early tree increase because these factors became operative only later.

\section{Effect of cutting, clearing, and planting on the forests}

BESIDES being instrumental in increasing the extent of the forests, man has affected the character of the forest cover in many other ways. Pre-1851 forests and woodlands were thinned by early settlers

Figure 9. A dense understory of incense-cedar is often found in forested areas on the Valley floor. The trees grow very slowly and may take over 20 years to reach a height of 6 feet. Photograph by R. P. Gibbens, 1962

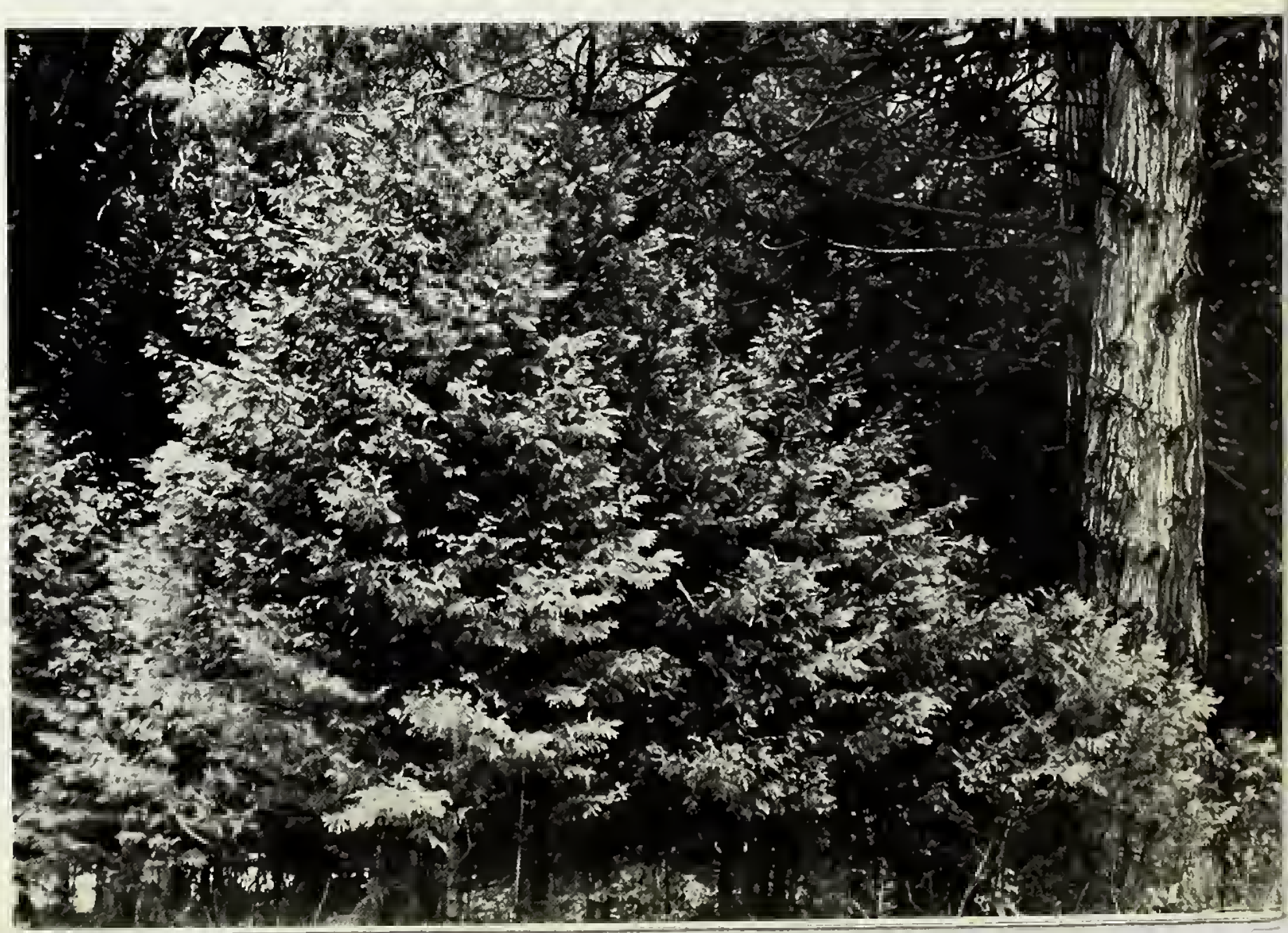




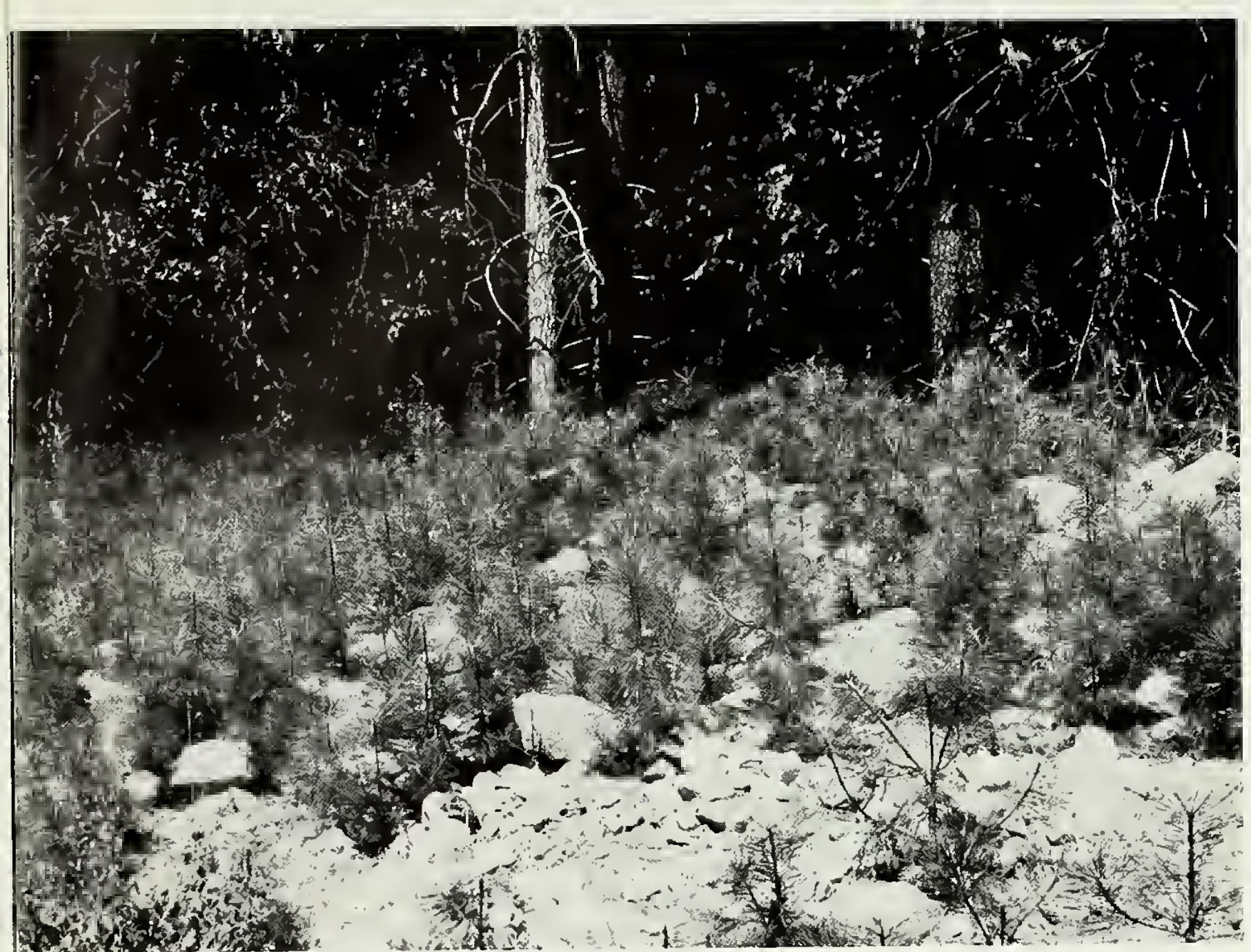

Figure 12. Young ponderosa pines at edge of a torrent channel between Cathedral Rocks and Sentinel Rock. Establishment of trees in open areas such as this has led to the dense stands now found in the Valley. Photograph by R. P. Gibbens, 1961

growing trees both from fires and natural destruction of its own, caused by rapid and dense growth.

There were approximately 150 acres cleared this season on the floor of the valley, and the work continues in connection with wood-cutting,

The objective of the clearing and thinning operations was set for the National Park Service in 1919, and the report of the landscape engineer (Punchard, 1919) appointed to study landscaping problems says:

Generally it was concluded that the present growth was greatly

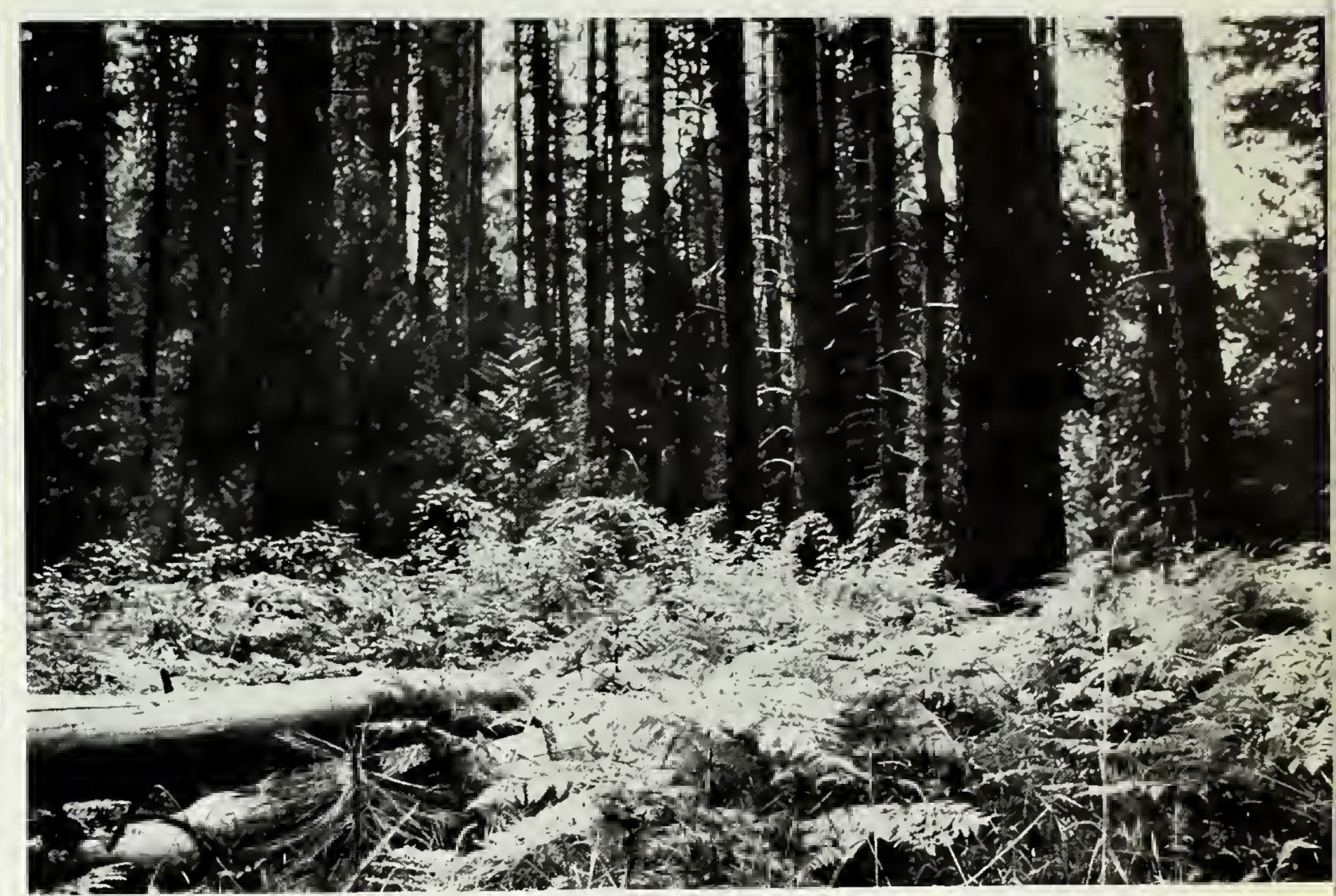

Figure 13. Understory of bracken fern (Pteridium aquilinum var. lanuginosumn) and western raspberry (Rubus leucodermis) characteristic of forests on low, wet sites on the Valley floor. Photograph by R. P. Gibbens, 1961.

in need of attention and that thinning on the floor of the valley should be undertaken for two reasons-first, to preserve the health of the larger trees and as a protection against serious fires, and, second, that thinning and clearing of the meadows would tend to open up and develop very interesting open spaces and vistas on the valley floor. It is not the intention to do this work in a drastic manner and reclaim the floor of the valley entirely and thus reproduce the conditions which existed at the time of the Indians, but to confine the work to such lines as will make the woodlands safer from the standpoint of fires and also produce a pleasing landscape effect. 


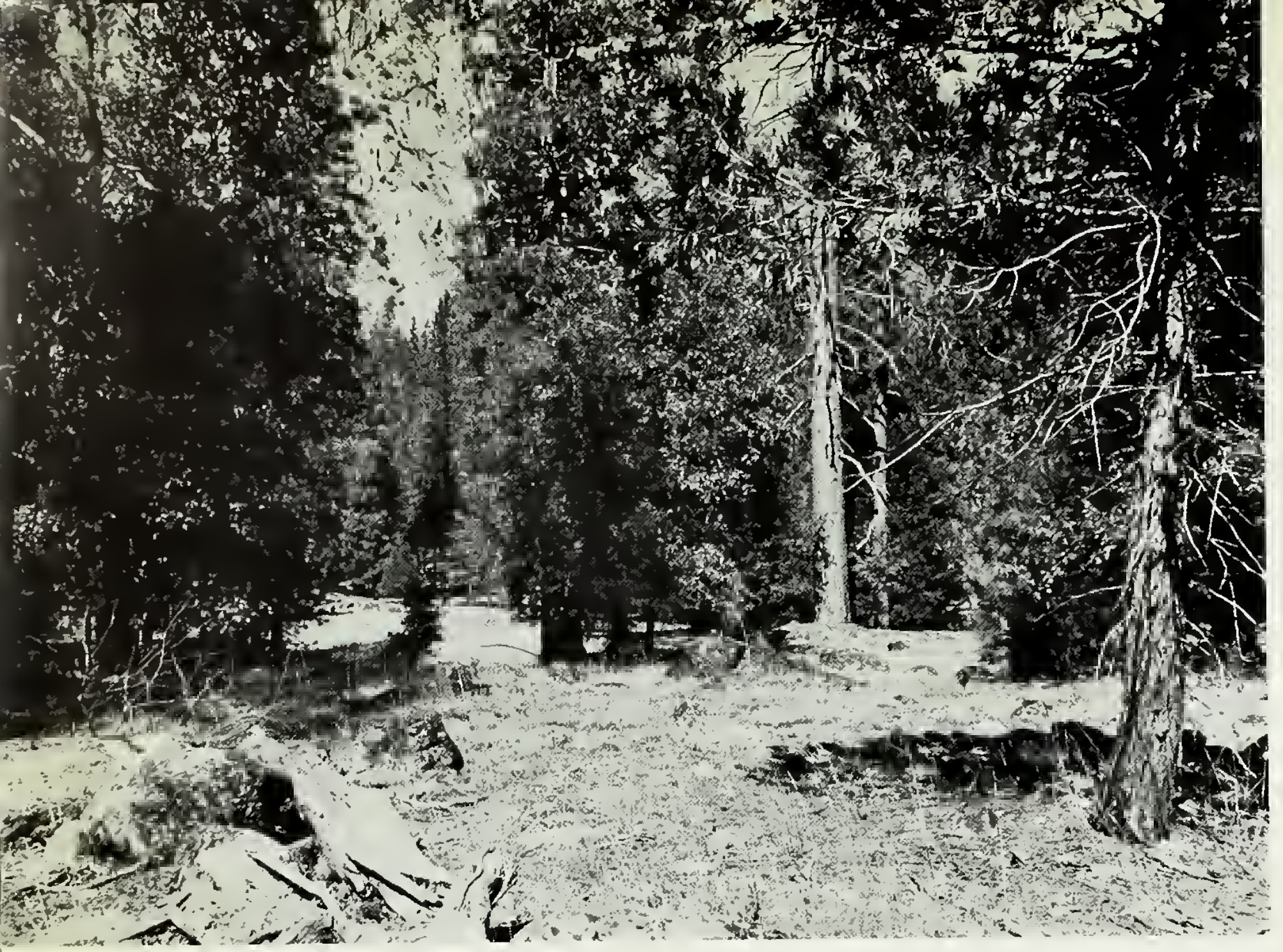

Figure 14. Forested area at base of talus slopes, where tree canopy is open and ground cover is usually sparse. Pine bluegrass (Poa scabrella) and lupine (Lupinus greyii) are the principal herbaceous plants. Photograph by R. P. Gibbens, 1961.

The vista-clearing concept was not new to the Valley-in the 1800's J. M. Hutchings had cut a lane through the trees so his guests would have a clear view of Yosemite Falls.

During the 1920's, wood and pole cutting was used to open vistas and thin trees in campground areas; cutting of insect-infested trees (which had begun in 1915) was also continued and some idea of the extent of tree-removal for all purposes is indicated by the 1,000 stumps blasted out along the roads in 1930. Oyster-shell scale also took a heavy toll of cottonwoods and willows during the 1920's. Thinning of trees and cleanup of dead brush and timber reached a peak during the Civilian Conservation Corps (CCC) days, and most of the Valley floor was affected. Such activities have been continued to a lesser degree to the present day. In addition to vista-clearing, snags and unsound trees are pruned or removed for public protection. Generally, such activities have had little effect on the extent of the forests, but constant thinning has influenced the relative abundance of species, particularly in campgrounds.

From about 1914 to 1924 some meadows were intentionally burned, killing many small trees and brush plants. In 1930, 9,170 small trees were cut from El Capitan meadow. In 1943, trees were again removed from El Capitan and other meadows (figs. 15A, $15 \mathrm{~B})$, but clearing did not end the problem of tree invasion in those meadows, as indicated by a 1961 photograph (fig. 15C).

Despite natural abundance, trees have also been planted at various times. Sequoia (Sequoia gigantea) and sugar pine were unsuccessfully planted along several roads in 1913, but in the CCC days, local species (primarily incense-cedar) were transplanted in order to screen barrow pits, campgrounds and comfort stations, and many of these trees still survive.
Figure 15A. Woodland in El Capitan Meadow, 1943. Young ponderosa pines are abundant. National Park Service photograph.

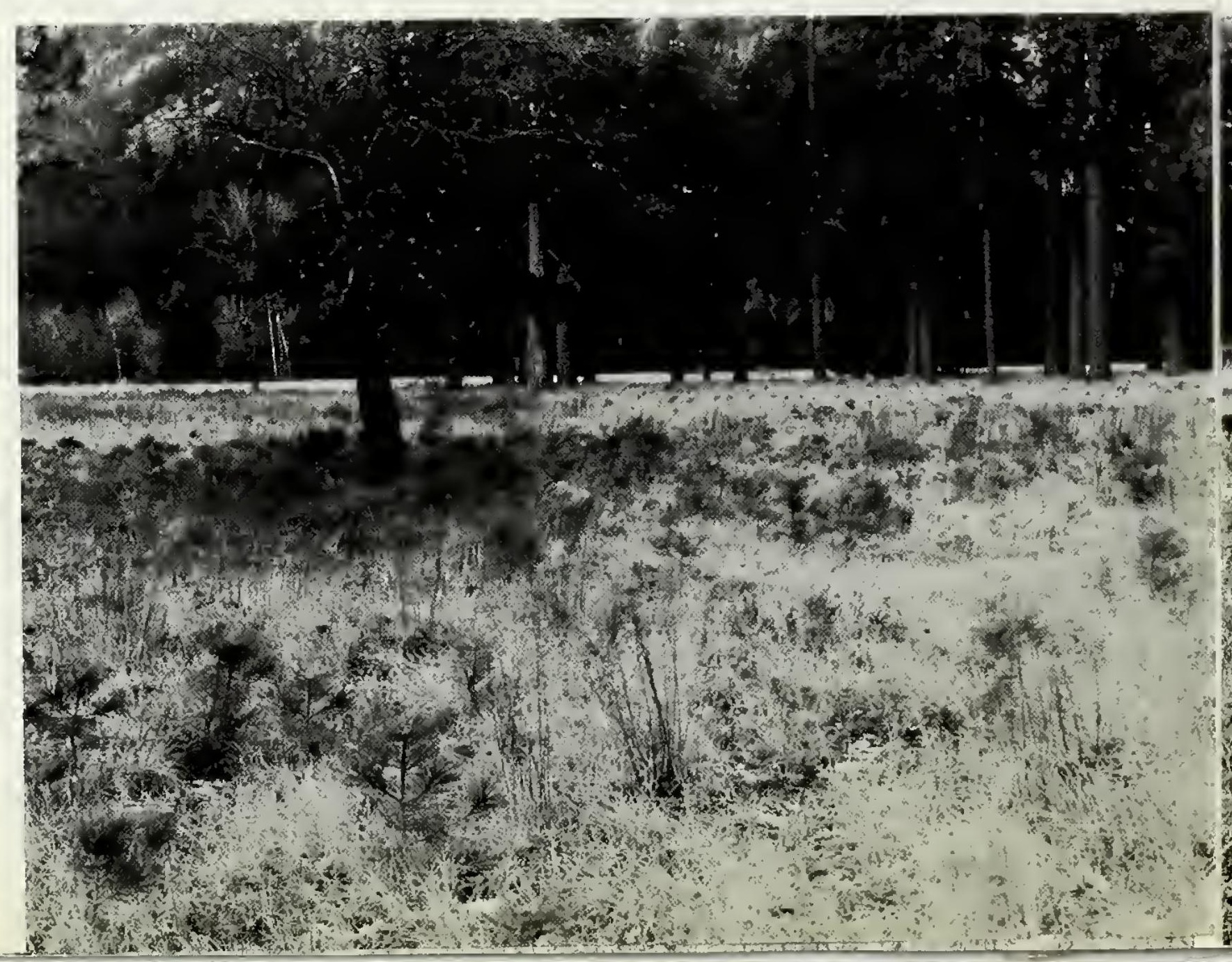




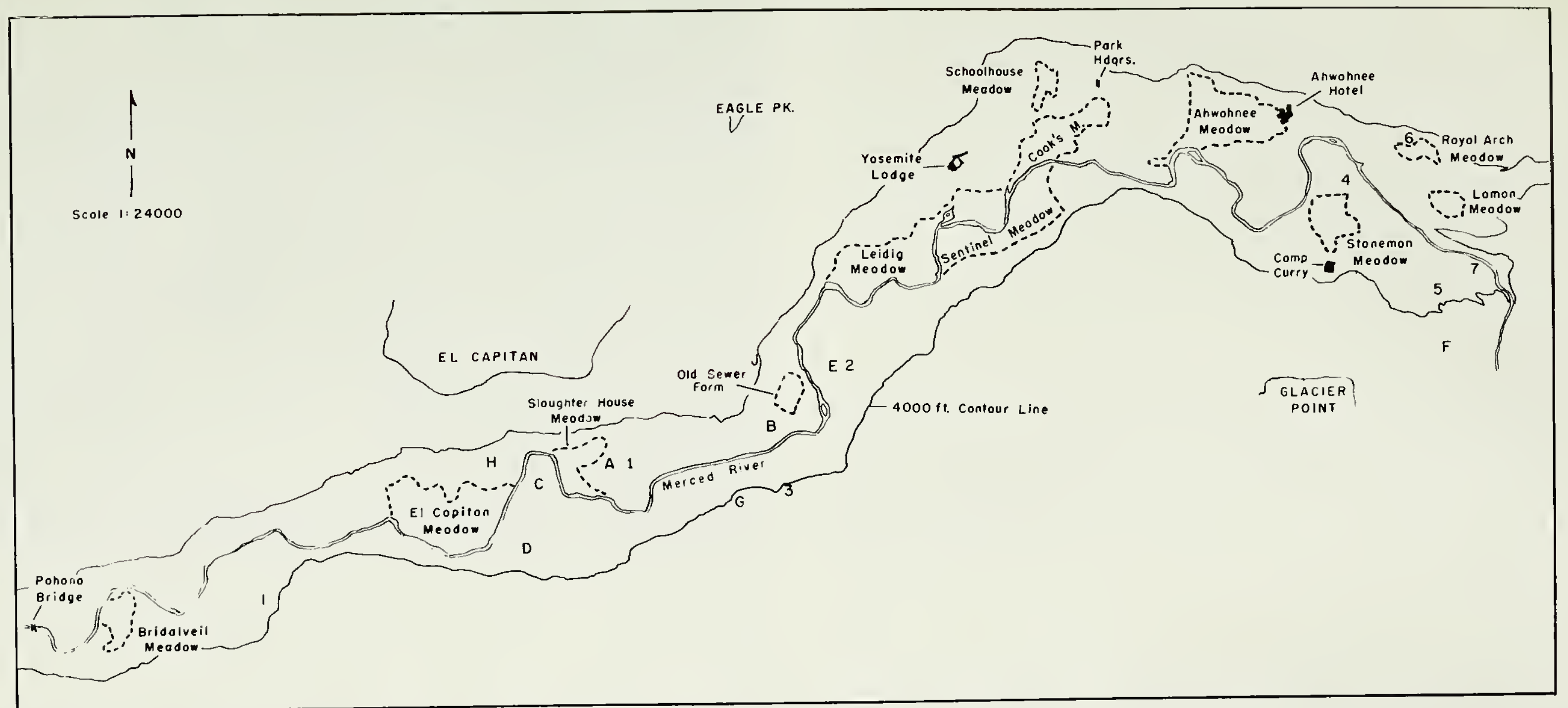

Figure 16. Map of Yosemite Valley showing the location of meadows and sampling sites.

shed in El Capitan Meadow; at least 20 acres of El Capitan Meadow was plowed and sown to timothy in the 1870's in an unsuccessful hay growing project, and Leidig Meadow was plowed in 1885 and 1887 to raise hay, and again in 1888 when wheat was sown. Part of the Ahwahnee Meadow was plowed during the late 1800's, and from 1910 to 1914 it was plowed and sown to hay by government employees. According to testimony at the Investigation of the Yosemite Valley Commissioners (California Legislature, 1889), Stoneman Meadow was cleared and plowed in 1887; the investigation placed the acreage under cultivation at that time at about 150 acres. Galen
Clark testified at the hearing that cultivation was considered a means of "reclaiming" meadowlands.

Portions of the Lamon, Stoneman, and Schoolhouse meadows were planted to orchards which still exist. The Schoolhouse Meadow was the site of gardening activities by $\mathbf{J}$. M. Hutchings, and by Valley residents during the two World Wars; hay barns and the Yosemite Park and Curry Co. warehouses were formerly located on this meadow. In 1941, small plots in El Capitan meadow were cultivated and sown to native plants in an unsuccessful attempt to re-establish wildflowers. Some of the meadows were drained for 
mosquito control. Ditching of unspecified meadow areas was done in 1932, and drainage tiles still exist in Royal Arch Meadow.

The old Sewer Farm is a man-made meadow (fig. 2B, 2C). In 1866 the area was covered by brush and probably developed a tree cover during the 70's and 80's. In 1921 it was cleared to provide space for settling basins of the first centralized sewage system, but with the completion of the present sewer plant in-1931 operations ceased and the dikes and tanks were leveled in 1932. Today the vegetation is essentially meadow-like in character, although some trees have become established.

Ahwahnee, Cook's and Bridalveil meadows were burned intentionally in 1919, 1920, 1921, and 1930. The Ahwahnee meadow was accidentally burned in 1929 , and other meadows probably have been burned by accident.

The problem created by tourists' use of the meadows (fig. 18) is mentioned in the Superintendent's Monthly Report for June, 1929:

\begin{abstract}
Ditches constructed around the meadows on the floor of the Valley have aided materially in protecting these spaces from encroachment by tourists. With autos traversing them constantly, and with daily picnics being held in these meadows, the native flowers and grasses were rapidly bccoming a thing of the past.
\end{abstract}

Figure 17. Dairy herd in Leidig Meadow, 1918. Until 1924, several meadows were grazed by dairy herds during summer months. National Park Service photograph

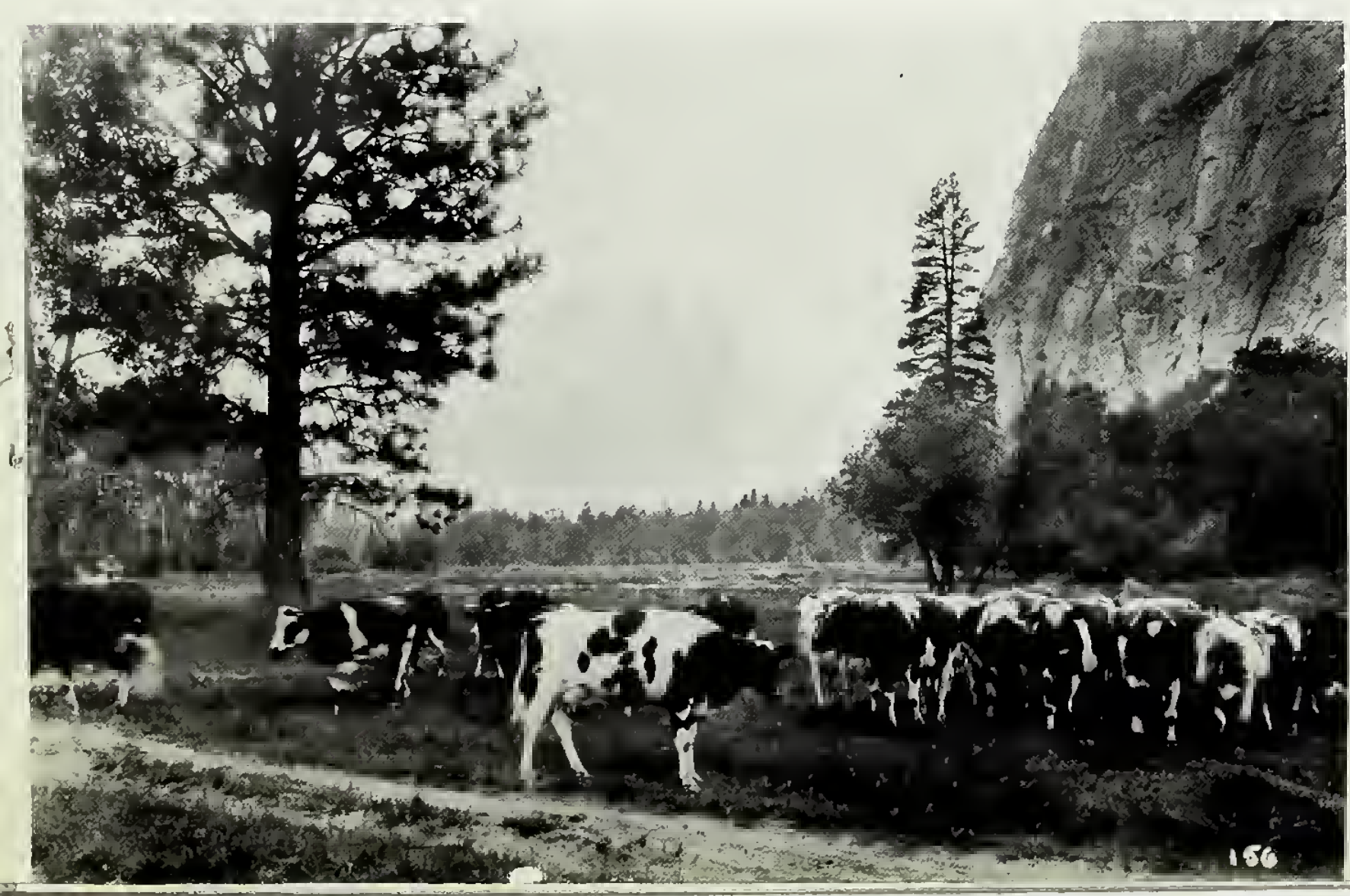

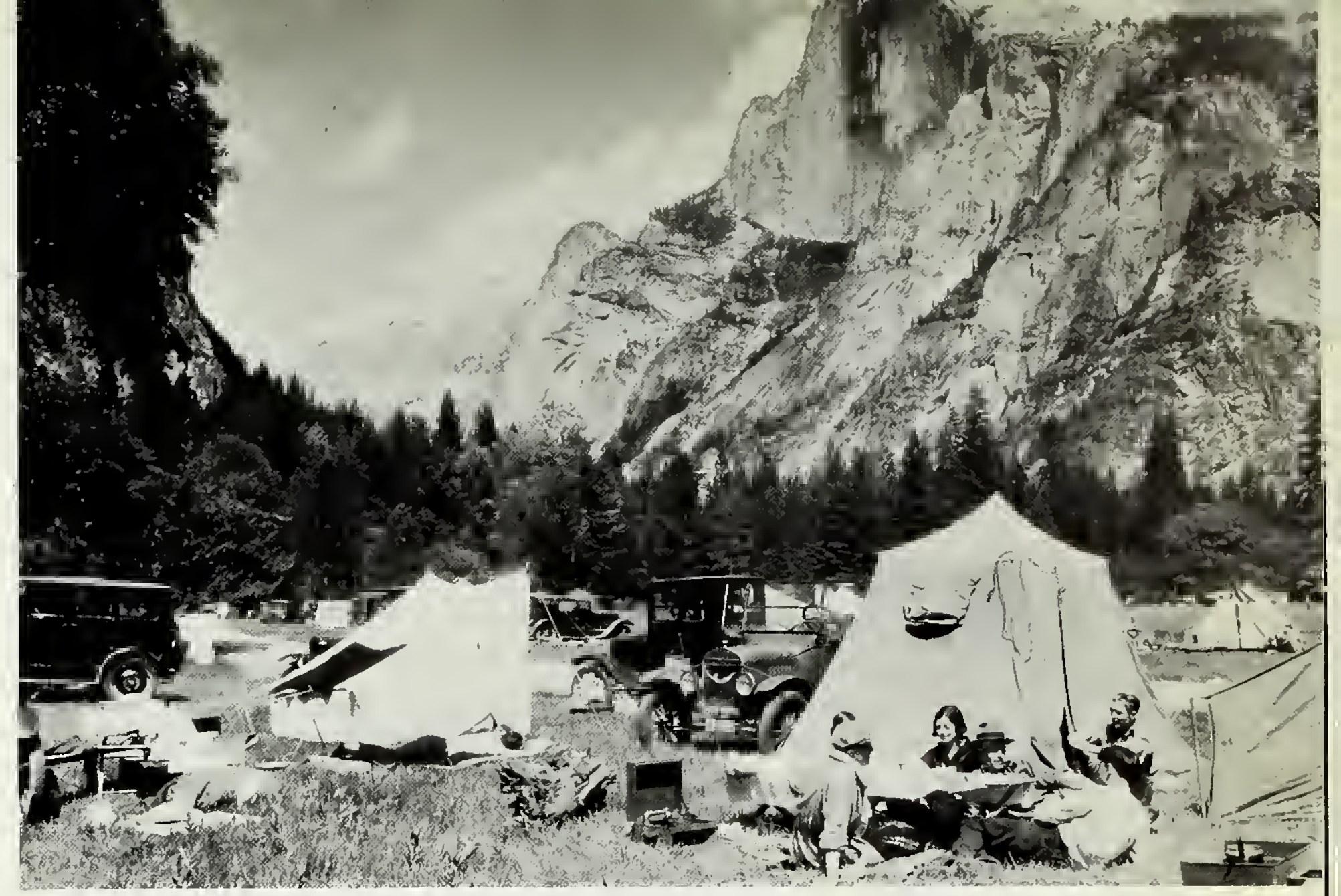

Figure 18. Stoneman Meadow as it appeared in May, 1927. Use of meadows for picnics and camping was common in the early 1900's. Construction of ditches along roadways in 1929 brought a halt to such use. National Park Service photograph.

Construction of these ditches ended the last general use of meadow areas; deer and other wildlife use the meadows today. Foot traffic is not extensive except in Stoneman Meadow and along the river banks. The remaining meadow areas are largely the product of man's activities. Plowing, mowing, burning, and probably in some cases severe overgrazing, served to keep out encroaching trees; in addition, clearing activities of the 1890's, 1930's and 1940's have prevented the establishment of woody growth. Boundaries of the present meadows could probably be correlated with the location of fences which delimited activities.

A major change in the meadows has been their decrease in size due to forest encroachment. Whitney (1868) classified 745 acres as meadowland. Russell (1927) using 1922 U. S. Geological Survey maps of Yosemite Valley placed the meadow acreage at 430 acres. 
drying action of trampling, but there are few low areas which are favorable for sedges. Soil factors may also play a part in species distribution.

Broad-leaved plants are not abundant on the meadows. There are many references through the years to the decreasing numbers of wildflowers in the meadows. Michael (1929) stated: "June of the year 1920 witnessed the last great bloom on the floor of the Valley."; she attributed the comparatively small numbers of flowers present in 1927 to the influence of mowing, burning, deer, and people, although these factors were also operative prior to 1920. The same author also noted that after being absent or nearly so from 1923 to 1935 , various lilies appeared in great abundance, even on meadows which had been plowed (Michael, 1935). Obviously, it is difficult to determine if wildflowers are now more, or less, abundant than in 1851 .

Abundant production of fruiting stalks by a wide variety of plants common to the lower Sierra Nevada is assumed to be climatically controlled. The optimum combination of moisture and temperature needed for such production in many species occurs only in widelyspaced years, and this helps account for the fact that myriads of flowers may be seen one year and only a few in another year. To blame the decline on grazing or some other factor is especially hazardous; valid comparisons should be based on the actual number of plants and not on the number of flower stalks.

Plowing, mowing, and grazing has undoubtedly reduced the population of certain wildflowers, while populations of some rare but attractive species have been decimated by picking and trampling. Perhaps the re-establishment of sod-forming sedges and grasses and the accumulation of a heavy mulch layer prevented the return of wildflowers after disturbance had ceased: It is also possible that lack of disturbance could decrease the wildflower populations; grazing, for example, would reduce mulch and weaken the sod-formers. Certainly, any species favored by burning is less likely to be found today than in 1851 . The great variety of wildflower species means that there will be some which will increase with disturbance and some which will decrease, some which will increase with protection and some which will decrease.

\section{Introduction of plants}

NUMERous plant species were brought to California by the Spaniards as early as the 16th century and many others have arrived since. Some of these scattered rapidly and by the middle of the 19th century were widespread and abundant in California (Burcham, 1957). Although the Spaniards rarely penetrated into the Sierra Nevada, the wanderings of Indians and natural dissemination by wind and animals could have introduced non-indigenous plants to the Valley before 1851 .

With the entry of early visitors a great importation of plants began, and conditions favorable for the establishment of introduced species were created. Plowing and heavy grazing broke up or weakened the cover of native plants, creating space readily occupied by the well-adapted introductions, many of which were brought in with the hay, grain, and seed imported for feed and cultivation. Seeds were widely disseminated over the Valley floor by grazing animals and by man, and disturbed areas were often deliberately seeded with plants foreign to the Valley. Out of 470 known species of plants on the Valley floor and lower portions of the talus slopes, 18 per cent are non-indigenous (appendix table 5).

Introduced trees and shrubs are not a significant part of the vegetation outside the orchards planted by the early settlers, although apple trees have naturalized to some extent. Introduced grasses which have become naturalized are very abundant. Kentucky blue- 
present distribution of species on such disturbed areas reflects moisture gradients and soil differences, and not the type of disturbance. The old Sewer Farm, for example, is now completely revegetated; where remnants of the old dikes impede drainage there is a dense cover of sedges, surrounded by wild-rye. Part of this area lies on the Eagle Creek outwash fan where rapid drainage and occasional deposition of material creates conditions ideal for abundant annual grasses. A few trees and shrubs have become established and, barring further disturbance, others are likely to appear.

In the spring of 1959 the Old Village store was removed, and in 1961 its site was sampled to determine the extent of recovery and the kinds of plants found on recently disturbed areas. Red fescue (Festuca rubra) had been sown on the site and was the most abundant plant, but annual weeds-characteristically the first invaders of denuded areas-were abundant (appendix table 6). Sedges and perennial grasses from the bordering meadow had gained a strong foothold on the site by 1961 . Young trees were not present at this time, but may appear while herbaceous cover is sparse.

Development of rhizomes by the dominant meadow plants enables them to move into disturbed areas very quickly, and perennials, when firmly established, crowd out annual species (see fig. 20C). Such disturbed areas may be identified for a long time, not because of species differences, but because of differences in plant size or color. On sandy or other dry sites introduced annual grasses, which are better adapted to less moisture than are perennials, may become the dominant plants.

Well-adapted native and introduced herbaceous species are the best choices for artificial revegetation of denuded areas. "Foreign" species, such as red fescue, may be successful temporarily but will usually be replaced by the natives. Trees may become established on denuded sites along with herbaceous plants, and may develop concurrently; when this happens the trees become dominant. Woody plants are often the primary invaders on rock slides; shrubs and young ponderosa pine trees were well established 9 years after a large rock slide at Rocky Point, but few herbaceous plants were present (Carlson, 1932).

\section{Wildlife Influences}

DEER and rodents are the animals most likely to significantly affect vegetation in Yosemite Valley. Although wildlife was protected in the Valley after 1864 , deer did not increase greatly until they were protected throughout Yosemite National Park, and by effective game laws outside the Park. The Acting Superintendent's Report of 1912 contains the first mention of an increased deer population; since then the population has fluctuated, with excess resident animals being removed when necessary.

Herbaceous plants constitute a major part of deer's diet, as browse plants are not abundant in the Valley. Some deer-relished plants, such as evening primrose (Oenothera hookeri), have apparently been reduced in abundance by the animals. Young white fir trees and favored shrubs are often hedged by browsing, thus greatly slowing their growth, and the limited reproduction of black oak (particularly in the grove surrounding Yosemite Village) has been attributed to deer browsing. A survey of the relatively deer-proof Ahwahnee Hotel grounds reveal a few small black oaks less than 1-foot tall, with one tree found outside the fence. As the grounds have been fenced since 1929, more young oaks and a number of different age groups would be expected if deer were the only limiting factor involved.

Black oak seedlings have appeared in large numbers at least once in relatively recent times. Payne (1938), commenting on the ex- 
ceptionally large crop of acorns produced in 1936, states: "With the lapse of a year since the sprouting of the acorns, we find a great host of these seedling oaks growing most vigorously." Reasons for the present scarcity of black oak reproduction are not known. Consumption of acorns may be a factor, but deer are not the only acorn users present. Any one of a number of factors-disease, insects, viability of acorns, competition from other plants, and climatic factors-may also be involved. Black oak grows very slowly and if perpetuation of the grove is desired efforts should soon be made to determine which factors are limiting reproduction.

Three exclosures were erected in 1935 to determine the effect of deer browsing and grazing, but little was learned save that deer seem to have had a minimum of influence on the vegetation. However, the exclosures are small and no record of vegetation on open control plots was compiled.

Rodents may possibly have played a part in the early spread of trees in the Valley. The bare soil of gopher-workings in meadows would make excellent seedbeds, and seeds buried in animals' caches would be a source of seedlings; however, during population peaks rodents could reduce tree-establishment by eating seeds and girdling young trees. Too little is known about the rodent populations to evaluate their effect on the vegetation, but such effects have been restricted by the rodent trapping and poisoning programs carried out since 1912.

Figure 21. Camp 14. Note absence of small trees, herbaceous cover, and heavy litter normally found under similar stands of trees. Photograph by R. P. Gibbens, 1961.

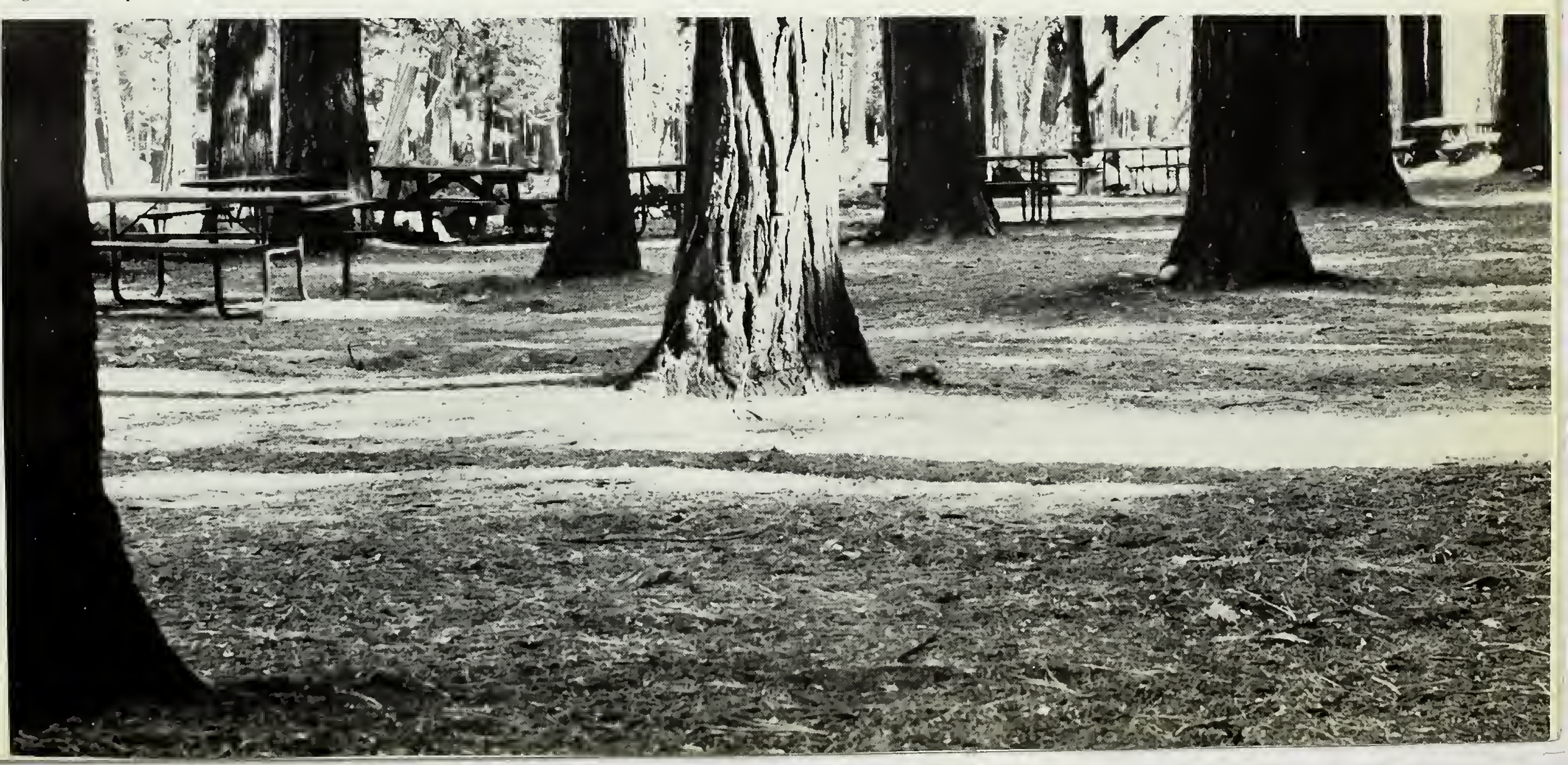




\section{Influence of floods and rockslides}

FLoods, rockslides, and avalanches have a catastrophic effect on vegetation. Major floods occurred in 1867, 1890, 1919, 1937, 1950 and 1955. Hutchings (1886) described the flood of 1867 as follows:

On December 23, 1867, after a snow fall of about three feet, a heavy down-pour of rain set in, and incessantly continued for ten successive days; when every little hollow had its own particular water-fall, or cascade, throughout the entire circumference of the Valley; each rivulet became a foaming torrent. and every stream a thundering cataract. The whole meadow land of the Valley was covered by a surging and impetuous flood to an average depth of nine feet. Bridges were swept away, and cverything floatable was carried off.

Immense quantities of talus were washed down upon the Valley during this storm.- morc than at any time for scores, if not hundreds, of years, judging from the low talus ridges, and the timber growth upon them. After this rain-storm had ceased. a wind sprung up and blew down over one hundred trees. In one spot of less than seven acres twenty-three large pines and cedars were pilcd, crosswise. upon. cach other.

Such floods inundate areas normally not flooded by spring runoff. The flood of 1950 covered 55 per cent of the nearly level floor of the Valley, and one in 1955 covered even more area. Floodwaters do not stand long enough to cause wholesale drowning of plants, but by erosion or deposition and changing of the river channel they can influcnce the abundance and growth of plants; for example, bare areas so created may be occupied by vegetation different from that previously existing in the same area.

Since 1879 there has been a continuing and not entirely successful struggle to confine the Merced River to its channel and to halt the cutting of banks, as both meadow areas and trees have been undermined and swept away by the river. Efforts to contain the river may have caused a deepening of the channel, and with such deepening, overflow is lessened, drainage is quicker, and the water table is lowered. These facts indicate that the low-lying ground may now be drier in summer than it was before 1851 .

Rockslides shear off or bury plants in their path, and several have occurred since 1851. The fall of Eagle Rock in the earthquake of 1872, which John Muir (1912) described so vividly, snapped off huge fir trees and covered a large area with a rubble pile many feet thick; much of this area is still bare of vegetation. Slides of lesser proportions (such as the one at Rocky Point in 1923) are not so longlasting in their effect. Wildfires can also have a catastrophic effect on vegetation, although most fires on the Valley floor have been quickly controlled.

Figure 22. Denuded and trampled river bank at west end of Camp 14. The pile of rock's is one of many efforts made to halt cutting of stream banks by the river. Photograph by R. P. Gibbens. 1961.

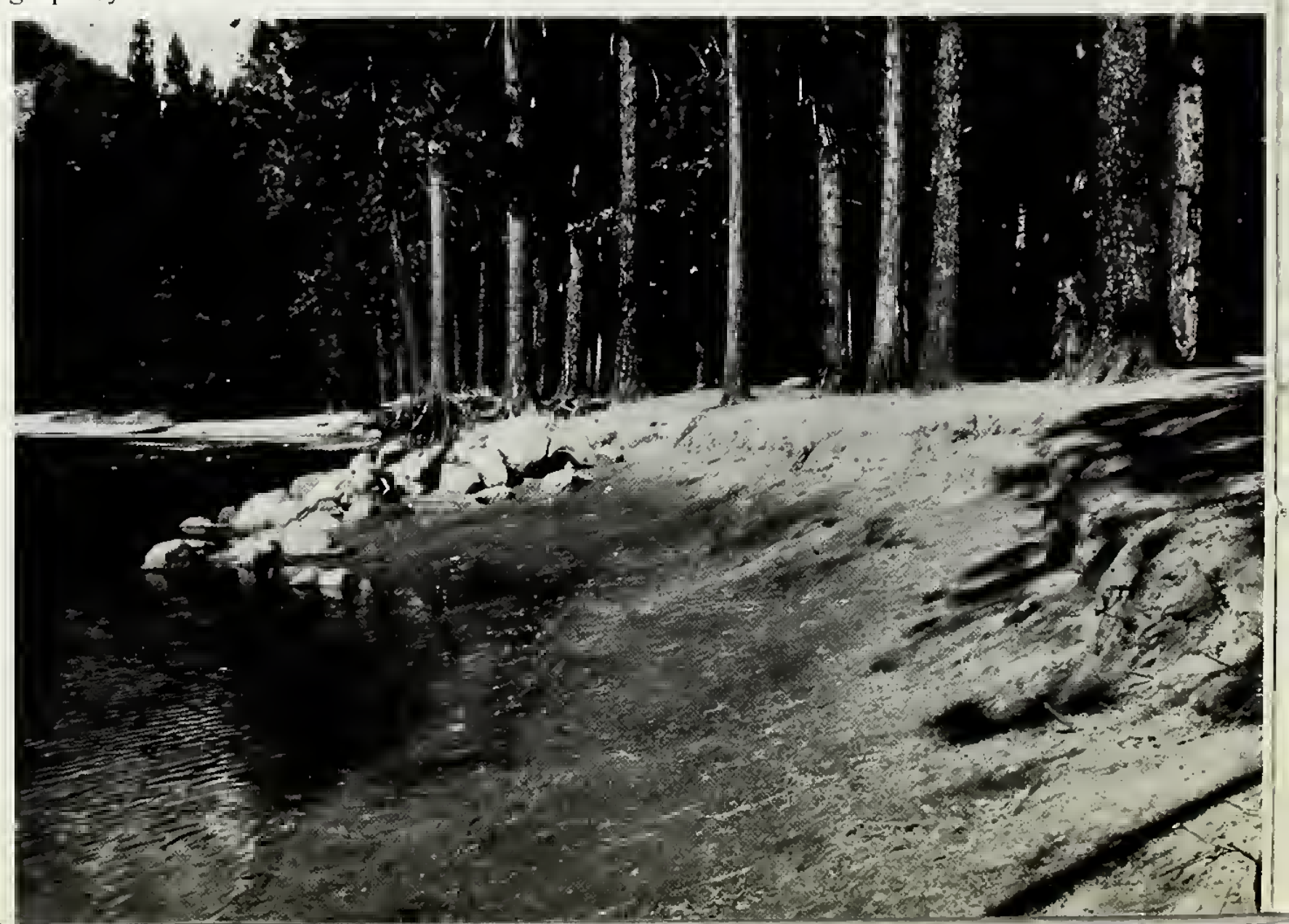




\section{Influence of visitors}

THE present boundaries of campgrounds in Yosemite Valley were established in the 1930's and these areas have born thc full impact of increasing use. During the summer of 1958 there were 8,800 to 12,000 campers in the Valley's campgrounds each night (National Park Service, 1958). Campgrounds in the Valley are all in forested areas, yet, with so many people moving about, the ground is devoid of herbaceous plants and young trees (fig. 21). Ernst (1947) lists only two plants, miner's lettuce (Montia perfoliata) and false Solomon's seal (Smilacina amplexicaulis), which appeared year after year in campground areas. Miner's lettuce produces seed before the peak of camping activity, and false Solomon's seal produces stems from underground rootstalks. Even adapted plants such as these can survive for only a short period each year.

Vehicular and foot traffic compacts soil, and this influences vegetation. Soil compaction in campgrounds was found to be significantly higher than in immediately adjacent areas (appendix table 7). Compaction dropped off sharply at campground boundaries, even though adjacent areas are subject to foot traffic. Compacted soils have less air space, lowered water infiltration rate, and increased runoffconditions which are unfavorable to plant growth.

The litter and duff layers characteristic of forest floors are reduced by campers. Pine needles, the principal constituents of litter and duff layers in the Valley's forests, make excellent kindling for fires and as a result are removed each year. In Camp 14 the litter collected in
September from 25 random square foot quadrats was equivalent to 2.5 tons of oven-dry material per acre. Under a similar stand of trees where camping was not an influence, litter and duff from 25 square foot quadrats was equivalent to 17.4 tons per acre. Of this amount 9.8 tons were duff, or largely decomposed organic matter, a layer that was non-existent in the campground. Larger debris has been removed for fuel from campgrounds and from the upper end of the Valley in general.

Constant removal of litter results in a loss of nutrients normally returned to the soil by the breakdown of organic matter. While leaching of campfire ashes and addition of material through spilled foodstuffs may partially offset this loss in nutrients, organic matterimportant in maintaining soil structure-and nitrogen are not replaced.

Because the Merced River bisects the campground area and is a focal point of activity, its banks are trampled bare (fig. 22). Before campgrounds were established the river banks supported a thick cover of shrubs and herbaceous plants; today, herbaceous plants are gone and the remaining azalea clumps have been broken by people (see all photographs in figure 23). River banks at favored bathing beaches and picnic areas also show the effects of trampling, but outside the areas of high human concentration trampling is largely confined to paths along the river.

An indication of what would happen in the present campgrounds if people were excluded was furnished by the temporary closing of campgrounds 7 and 15 during 1943,1944, and 1945 (Ernst, 1947). Tree seedlings appeared and herbaceous plants recovered rapidly, especially near protected spots and guard rails at camp boundaries where the seed source was located. Several campgrounds, abandoned for sanitary reasons soon after 1906 and still not in use as campgrounds, now show no evidence of past trampling.

Buildings and roads continue to influence the vegetation. Buildings serve as focal points of human activity, and trampling often creates disturbed areas around them. Extensive walks and paved areas have reduced trampling, but the runoff from such non-absorptive surfaces influences vegetation on adjacent areas. 


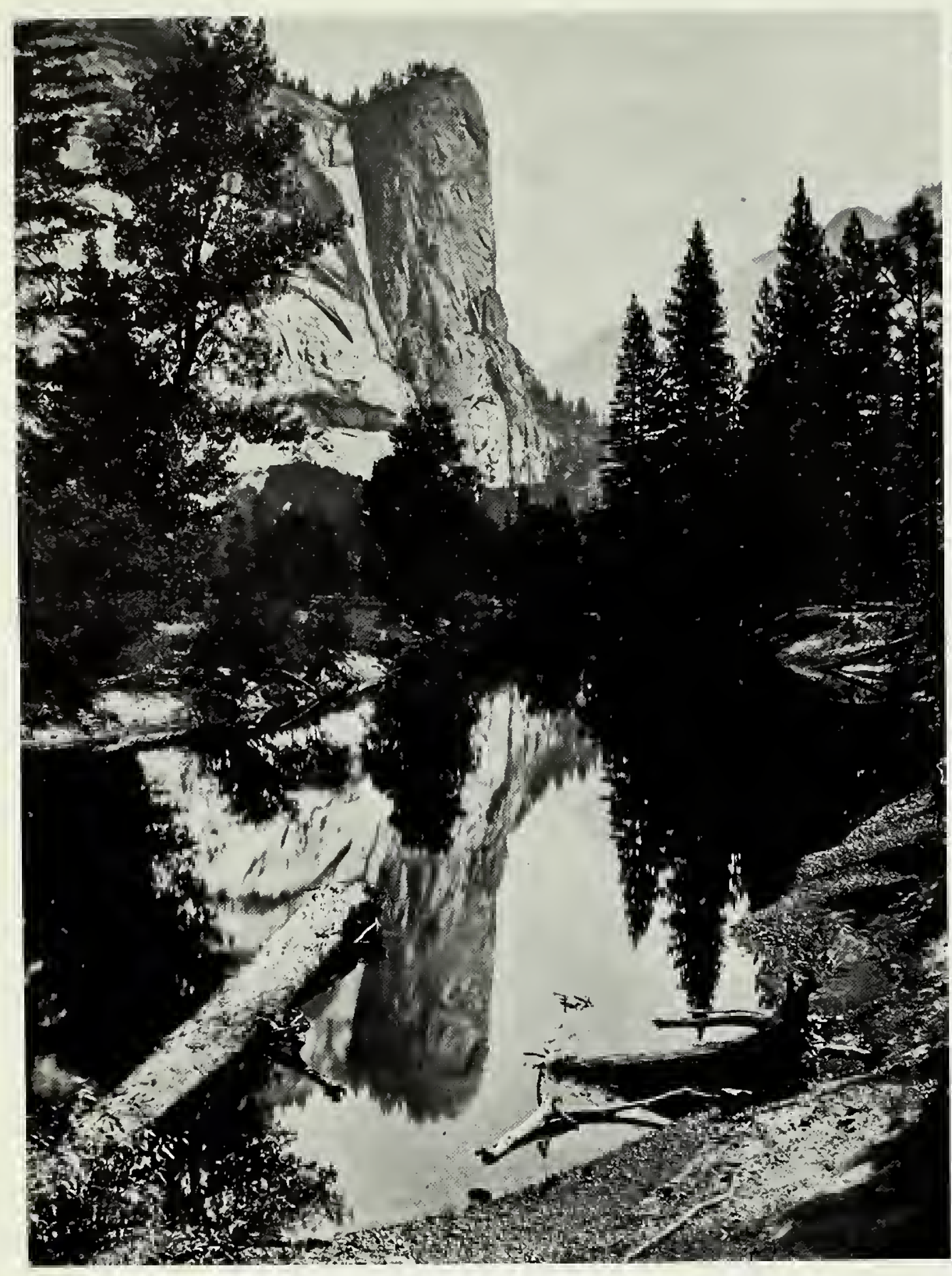

Figure 23A. Early photograph taken from below the present site of Stoneman Bridge. (Washington Column in background.) Photographer and date unknown.

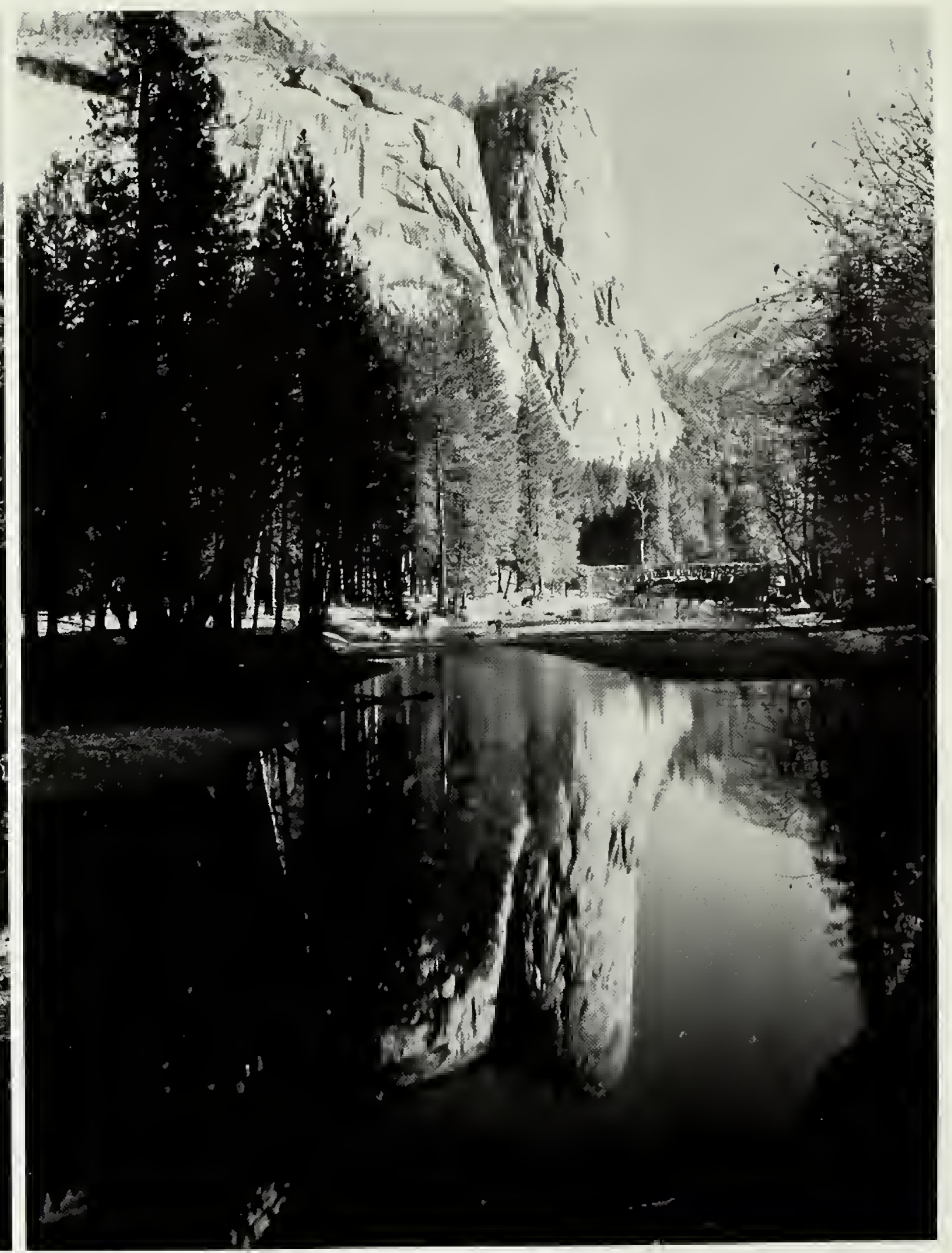

Figure 23B. The river below Stoneman Bridge, 1943. River bank on the left borders Camp 7; shrubs and herbaceous plants have been trampled out by campers. National Park Service photograph. 
can be obtained by selective cutting, although it would probably be impractical to thin the forests to their primitive low-density. However, some thinning must be done for other than aesthetic reasons: a dense understory of young trees often forms a solid block of fuel from the ground to the tallest tree tops, and this is a potentially catastrophic situation if fire occurs.

Although perhaps undesirable in some areas, dense stands of trees are useful in screening the Valley's extensive campgrounds from view. In the campgrounds a preponderance of sandy soils has minimized the effect of trampling, but the soils have been altered and the present tree cover may be adversely affected. Since there is a lack of young trees in these areas, a time limit - the life span of the existing trees-has been placed on the screening forest. Therefore, steps to protect tree health and to provide replacements for dead or dying trees should be taken. One solution might be to rotate campground use; during periods of closure an understory of herbaceous species could be established by sowing, and replacement trees could be planted.

To maintain the meadows in the Valley as open areas will require continued removal of trees. Selective tree removal is expensive but effective. Other methods, such as prescribed burning, might be less costly or more long-lasting, but their effect on herbaceous vegetation would have to be evaluated before they are used on a large scale.

The presence of the many introduced herbaceous plants in the meadows must be accepted because they cannot be completely and permanently eradicated. And indeed, many of these introductions are desirable. On Stoneman Meadow, for example, Kentucky bluegrass maintains a pleasing appearance despite trampling which would cause more robust native sedges to become unsightly. Again, introduced annual grasses provide cover on many areas too dry to support a good cover of perennials. Only those introductions which detract from scenic values need to be controlled. It is unlikely that the sedges, which add much to the attractiveness of the meadows, will be replaced by other plants as long as present moisture conditions prevail. Creation of wetter conditions by changing drainage patterns might be an effective method of increasing the numbers of sedges and other moisture-loving plants.

There is, of course, an alternative to management of the vegetation, and that is the acceptance of the landscape which will develop naturally. This alternative has been consistently rejected in the past, and, if aesthetic criteria are used, continued rejection is likely in the future.

\section{Acknowledgments}

THIS STUDY was made possible by contract funds from REGiON IV of the National Park Service during 1961-62. In addition, the interest and cooperation of many individuals on the staff of Yosemite National Park allowed the study to progress rapidly. Their help is greatly appreciated. Especially, we thank Keith Trexler, Coyt Hackett, and Douglas Hubbard for their many suggestions in locating source materials, opening museum facilities, and improving the manuscript.

C. W. Sharsmith identified many of the plants mentioned; Mr. and Mrs. A. W. Hood allowed the use of their excellent collection of early photographs and gave many tips on the location of historical information and field sites; A. M. ScHULTZ made many suggestions for inproving the manuscript. Their help is gratefully acknowledged. 


\section{Literature cited}

Acting Superintendent of Yosemite National. Park

1895 to 1915 . Annual Reports. U. S. Govt. Printing Office, Washington.

BAXLEY, H. WILLIS

1865. What I saw on the west coast of South and North America. D. Appleton \& Co., Ncw York. $632 \mathrm{p}$

BRYANT, WAYNE W.

1951. A brief survey of biotic distribution and its physical environment in a transect across Yosemite Valley, California. MS thesis. Dept. of Zoology, Utah State Agr. Coll. Logan. Utah. 142 p.

BunNell, Lafayette Houghton

1911. The discovery of Yoscmite and the Indian War of 1851. G. W. Gerlicher, Los Anglees. 4th ed. 355 p.

BURCHAM, L. T.

1957. California Range Land. Div. of Forestry, Dept. of Natural Resources. State of Calif., Sacramento. 261 p.

California Legislature

1889. In the matter of the investigation of the Yosemite Valley Commissioners. Calif. State Printing Office, Sacramento. 430 p.

CARLSON, REYNOLD E.

1932. Plant succession at Rocky Point. Report for Yosemite Field School of Natural History. Filed in Yosemite Museum Research Library. Yosemite National Park, Calif. Typewritten. 21 p.

Clark, Galen

1894. Letter to the Commissioners. In Bicnnial Report of the Commissioners to manage Yosemite Valley and the Mariposa Big Trce Grove. 1893-1894. Calif. State Printing Officc, Sacramento.

Commissioners to Manage the Yosemite Valley and the Mariposa Big Tree Grove.

1874 to 1904. Biennial Reports. Calif. State Printing Office, Sacramento.
Cottam, G., and J. T. Curtis

1956. The use of distance measures in phytosociological sampling. Ecology 37:451-60.

Durant, Marafred

1927. A comparison of the flora of the Ahwahnee meadow and the Royal Arches meadow. Report for Yosemite Field School of Natural History. Filed in Yosemite Museum Research Library. Yosemitc National Park, Calif. Typewritten. 5 p.

ERNST, EMIL F.

1943. Preliminary report on the study of the meadows of Yoscmite Valley. Unpublished document in the Forester's Office, Yosemitc National Park. File No. 880-01. 68 p. plus photographs.

1947. Results of retirement and rest during 1943-44-45 of campgrounds 7 and 15 Yosemite Valley. Report filed in Forester s Office. Yosemite National Park. Calif. 7 p.

1949. Vanishing meadows in Yosemite Valley. Yosemite Nature Notes $38: 34-40$.

1961. Forest encroachment on the meadows of Yosemite Valley. Sierra Club Bul. 46(8):21-32.

\section{Goen, Alice}

1932. Comparison of the vegetation on the north and south facing talus slopes. Report for Yosemite Field School of Natural History. Filed in Yoscmite Museum Rescarch Library. Yosemite National Park, Calif. Typewritten. 7 p.

\section{HALL, WM. HAM.}

1882. To preserve from defacement and promote the use of the Yosemitc Valley. Report of State Engineer. In Biennial Report of the Commissioners to Manage the Yosemite Valley and the Mariposa Big Tree Grove. 1882. Calif. State Printing Office, Sacramento.

\section{Hutchings, J. M.}

1880. Guardians report. In Report of the Commissioners to Manage the Yoscmite Valley and the Mariposa Big Tree Grove. 1880. Calif. State Printing Office, Sacramento.

1882. Guardians report. In Report of the Commissioners to Manage the Yosemite Valley and the Mariposa Big Tree Grove. 1882. Calif. State Printing Office, Sacramento.

1886. In the heart of the Sierras. Pacific Press Pub. House. Oakland. Cilif. 496 p.

1888. The Yosemite. San Francisco Examiner. July 29, 1888. San Fran cisco, Calif.

LILLARD, RICHARD G.

1948. Exotic plants in Yosemite Vallcy. Yosemite Nature Notes 27:100-1. 
Matthes, Francois E.

1930. Geologic history of the Yosemite Valley. U. S. Geol. Survey, Prof Paper 160. U. S. Govt. Printing Office, Washington. 137 p.

MCDonald, Louise O.

No date. A comparison of plants found in Royal Arches meadow and in Kenneyville meadows. Report for Yosemite Field School of Natura History. Filed in Yosemite Museum Research Library. Yosemite National Park, Calif. Typewritten. 6 p.

Michael, ENID

1929. Brief survey of the plants of Yosemite National Park, p. 162-71. In Yosemite Ranger-Naturalist Manual Vol. II, 2nd ed. National Park Scrvice. Processed.

1935. A good flower year. Yosemite Naturc Notes 14:96-7.

MUIR, JOHN

1912. The Yosemite. The Century Co., New York. 284 p.

1915. Letters to a friend. Houghton Mifflin Co., New York. 194 p.

Munz, Philip A. and David A. KeCK

1959. A California flora. Univ. of Calif. Press, Berkeley, Calif. 1681 p.

National Park Service

1958. Monthly travel reports, File No. A3015. Yosemite National Park. Calif.

Paden, Irene D. and Margaret E. Schlichtmann

1955. The Big Oak Flat road. San Francisco, Calif. 356 p.

PAYNE, E. A.

1938. Natural wholesale planting of California black oak in Yosemite Valley. Yosemite Nature Notes 17:121-22.
Punchard, Chas. P., JR.

1919. Report of the landscape engineer. In Report of the Director of the National Park Service. 1919. U. S. Govt. Printing Office, Washington.

REYNOLDS, RICHARD DWAN

1959. Effect of natural fires and aboriginal burning upon the forests of the central Sierra Nevada. MA thesis. Geography Dept., Univ. of Calif., Berkeley. 262 p.

Russell, CARL P.

1927. What becomes of our mountain meadows. Yosemite Nature Notes $6: 37$.

1959. 100 years in Yosemite. Yosemite Natural History Assoc. Inc. Yosemite National Park. Calif. 206 p.

SAN Francisco Examiner

November 26, 1888. Yosemite vandalism. San Francisco, Calif.

SECRETARY OF INTERIOR

1892. Annual Report. U. S. Govt. Printing Office, Washington.

Superintendent of Yosemite National Park

1924 to 1946. Monthly Reports, File No. 207-002.3. Yosemite National Park, Calif.

WHITNEY, J. D.

1868. The Yosemite book. Julius Bien, New York. 116 p. 28 plates, 2 maps.

WOODHAM, E. M.

1927. The grass carpet on Yosemite's floor. Yosemite Nature Notes $6: 76-7$. 


\section{Bibliograpby}

Ayres, Thomas A.

1855 and 1856. Original pencil drawings made in Yosemite Valley. Yosemite Museum exhioits. Yosemite National Park, Calif.

Bade, William Frederic

1923. The life and letters of John Muir. Vol. I. Houghton Mifflin Co., New York. 399 p.

BENNYHOFF, JAMES A.

1956. An appraisal of the archeological resources of Yosemite National Park. Univ. of Calif. Archaeol. Survey No. 31. Processed. 71 p.

BORELL, A. E.

1933. Yosemite elk herd moved to Owens Valley. Yosemite Nature Notes 12:107-9.

Century Magazine

1890. Editorial. Amateur management of the Yosemite scenery. 17:79798.

Clark, Galen

1907. A Yosemite plea of 1907. Published posthumously in Yosemite Nature Notes 6:12-15. 1927.

COOper, William S.

1922. The broad-sclerophyll vegetation of California; an ecological study of the chaparral and its related communities. Carnegie Inst. Wash. Publ. 319. 124 p.

Dixon, J.S.

1934. A study of the life history and food habits of mule deer in California Calif. Fish and Game, 20: Part I 181-282, Part 1I 315-54.

Engineering and Maintenance Division, Yosemite National Park

1950. Flood damage, repair and reconstruction estimates. Report filed in Park Engineer's Office, Yosemite National Park, Calif

1955. Summary and highlights of the 1955 flood in Yosemite National Park. Report filed in Park Engineer's Office, Yosemite National Park, Calif.

ERNST, EMIL F

1943. Supplement to the preliminary report on the study of the meadows of Yosemite Valley. Unpublished collection of photographs in the Forester's Office, Yosemite National Park, Calif. 4 p. plus photographs.

Gutenberg, Beno, John P. Buwalda, and Robert P. Sharp

1956. Seismic explorations on the floor of Yosemite Valley. Bul. of the Geol. Soc. of Am. 67:1051-78.

ISE, JOHN

1961. Our National park policy. John Hopkins Press, Baltimore. 701 p.

MUIR, JOHN

1890. The treasures of the Yosemite. The Century Magazine 18:483-500

National Park Service

1940-42. Wildflower Garden (El Capitan Exp. Garden Plots), File No. 833-01.3. Yosemite National Park, Calif.

1961. Travel Statistics, File No. A88. Yosemite National Park, Calif.

Olmsted, Frederick LaW

1865. The Yosemite Valley and the Mariposa big trees. Introduction by Laura Wood Roper. Landscape Architecture 43(1) : 12-25.

SOVUlEWSKI, Gabriel

1937. The story of campgrounds in Yosemite Valley. Yosemite Nature Notes 16:81-4.

Superintendent of Yosemite National Park

1916 to 1930. Annual Reports. In Report of the Director of the National Park Service. U. S. Govt. Printing Office, Washington.

U. S. Geol. Survey

1921. Map of Yosemite Valley. Based on surveys made in 1919. Scale $1: 2400.5$ sheets.

1961. Map of Yosemite Valley. Based on 1955 aerial photographs. Scale 1:24000. I sheet.

Wheeler, Capt. Geo. M

1833. Topographical map of Yosemite Valley and Vicinity. Prepared from data collected in 1878-79. Scale $1: 42240.1$ sheet. 


\section{Appendix}

\section{METHODS OF STUDY}

The quarter method (Cottam and Curtis, 1956) was used to sample trees in seven forest stands on the Valley floor. A line of march was selected, 100 feet paced off, and a plot center established by means of a rod placed at the toe of the boot. With the line of march

APPENDIX TABLE I

RELATIVE ABUNDANCE OF TREES WITH A D.B.H. OF 2 INCHES OR MORE EXPRESSED AS PERCENTAGE OF TOTAL NUMBER OF TREES CONTRIBUTED BY EACH SPECIES*

\begin{tabular}{|c|c|c|c|c|c|c|c|}
\hline \multirow[b]{2}{*}{ Species } & \multicolumn{7}{|c|}{ Site Number } \\
\hline & 1 & 2 & 3 & 4 & 5 & 6 & 7 \\
\hline & \multicolumn{7}{|c|}{ percent } \\
\hline Pinus ponderosa..... & 40 & 45 & 54 & 56 & 26 & 59 & 12 \\
\hline Libocedrus deeurrens. & 53 & 39 & 29 & 37 & 56 & 28 & 20 \\
\hline Quercus kelloggii..... & 4 & 11 & 14 & 2 & 16 & 8 & 7 \\
\hline Abies concolor..... & 3 & 4 & 1 & 5 & 1 & 5 & 54 \\
\hline Quereus chrysolepis... & 0 & 1 & 2 & 0 & 0 & 0 & 2 \\
\hline Pseudotsuga menziesii. & 0 & 0 & 0 & 0 & 1 & 0 & 4 \\
\hline Cornus nuttallii...... & 0 & 0 & 0 & 0 & 0 & 0 & 1 \\
\hline
\end{tabular}

* Calculated from 25 quarter-method samples taken on each of seven forest sites located on the Valley floor (see figure 16 for site locations). as one axis and a line at right angles to it as another axis, four 90 degree angles, or quarters, were established. The tree over 2 inches d.b.h. (diameter breast high) nearest to the pin was measured and recorded by tree species for each quarter. In each stand, 25 points were sampled, giving 100 measured individuals. From these data the relative abundance as based on number of individuals (appendix table 1) and on basal area (appendix table 2) was calculated.

The relative abundance of herbaceous plants and trees on ten forest sites was calculated from data collected by a modified steppoint method of sampling (appendix table 3 ). Three steps were taken along a compass line and a pin placed at the toe of the front boot. The closest rooted plant in front of the pin was recorded. The rooted plant closest to the step-point was somctimes a tree, recorded as mature, young (under 4 inches d.b.h.), or seedling ( 1 and 2 years old for conifers, under 1 foot for oaks). The seedling designation for oaks was used merely to distinguish recent reproduction. This is not an ideal method to use in a forest because two different

APPENDIX TABLE 2

RELATIVE BASAL AREA OF TREES WITH A D.B.H. OF 2 INCHES OR MORE EXPRESSED AS PERCENTAGE OF TOTAL BASAL AREA CONTRIBUTED BY EACH SPECIES*

\begin{tabular}{|c|c|c|c|c|c|c|c|}
\hline \multirow[b]{2}{*}{ Species } & \multicolumn{7}{|c|}{ Site Number } \\
\hline & 1 & 2 & 3 & 4 & 5 & 6 & 7 \\
\hline & \multicolumn{7}{|c|}{ percent } \\
\hline Pinus ponderosa... & 64.2 & 68.0 & 54.2 & 62.3 & 54.4 & 86.5 & 33.3 \\
\hline Liboeedrus deeurvens. & 29.1 & 20.0 & 29.3 & 29.9 & 35.4 & 10.7 & 17.7 \\
\hline Quereus kelloggii.... & 6.5 & 9.4 & 16.3 & 3.1 & 8.9 & 1.6 & 9.4 \\
\hline Abies concolor..... & 0.2 & 2.5 & 0.1 & 4.7 & 0.9 & 1.2 & 31.4 \\
\hline Quereus ehrysolepis... & 0.0 & 0.1 & 0.1 & 0.0 & 0.0 & 0.0 & 1.1 \\
\hline Pseudotsuga menziesii. & 0.0 & 0.0 & 0.0 & 0.0 & 0.4 & 0.0 & 7.0 \\
\hline Cornus nuttallii...... & 0.0 & 0.0 & 0.0 & 0.0 & 0.0 & 0.0 & 0.1 \\
\hline
\end{tabular}

* Calculated from 25 quarter-method samples taken on seven forest sites on the Valley floor (see figure 16 for site locations). 


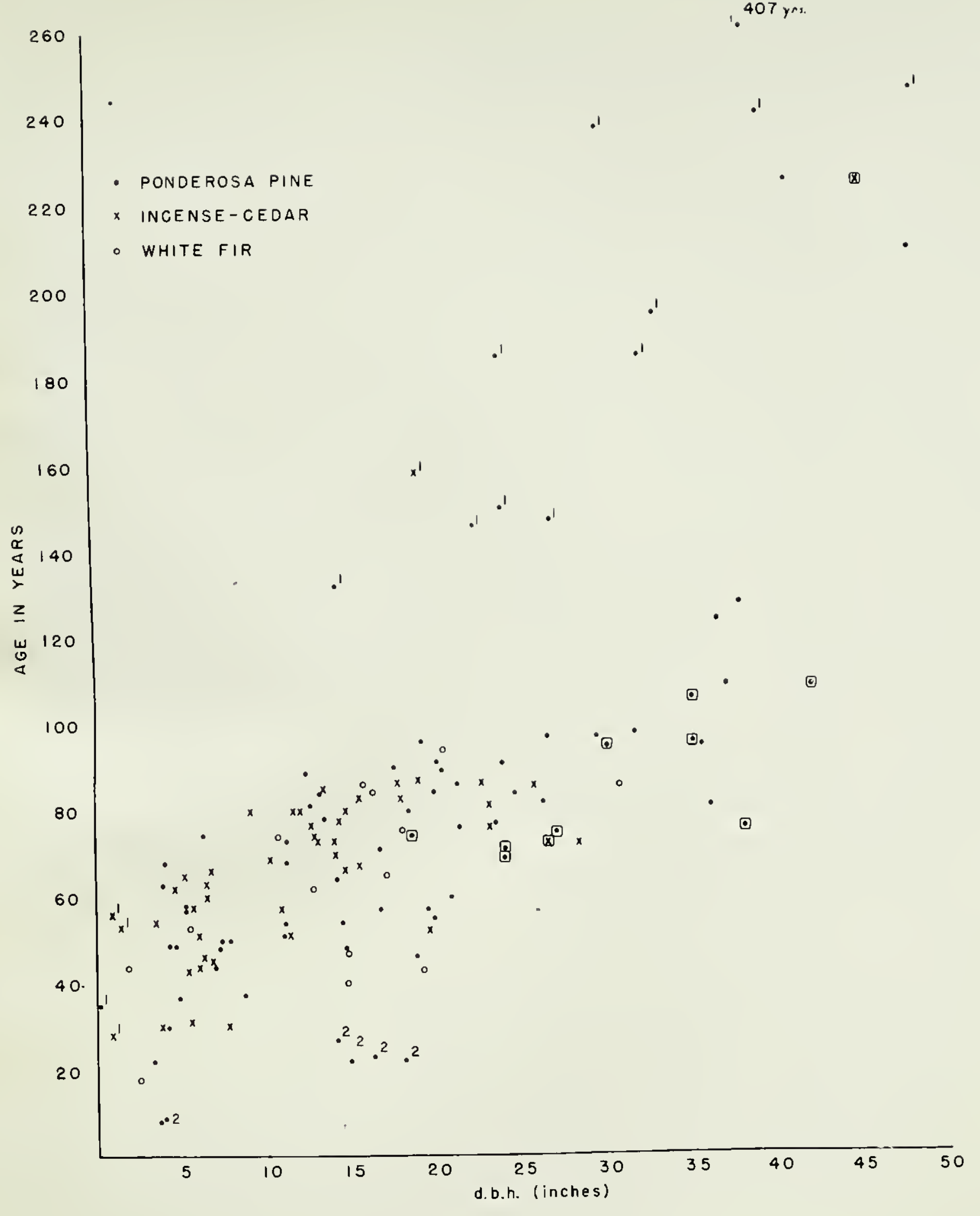

life forms-trees and herbaceous plants-are intermixed, but it was a rapid method and furnished a measure of the relative abundance of the different species. The number of trees recorded indicates their relative proportion in the total vegetation.

The relative abundance of species on the meadows was calculated from rooted frequency as determined by the modified step-point method described above (appendix table 4). Due to scarcity of fruiting bodies and lack of distinctive vegetative differences the species of sedges could not always be distinguished. However, the principal species in approximate order of abundance were Carex barbarae, $C$. vesicaria, $C$. feta, and $C$. kelloggii. Wild-rye was not separated into species due to the intergradation of forms. In general Elymus triticoides is found in open areas and E. glauca in wooded areas. Species listed as "other perennial grasses" in appendix table 4 include Stipa californica, S. columbiana, Muhlenbergia filiformis, $M$. rigens, Panicum occidentale, and Calamagrostis canadensis; "other annual grasses" include Bromus commutatus, Festuca reflexa, F. dertonensis, and Deschampsia danthonoides. Only the most common forbs are listed in appendix table 4. Nomenclature is based on Munz and Keck (1959).

\section{APPENDIX FIGURE 1 .}

Total age of trees as estimated from growth ring counts in 1961. The range of d b.h classes (diameter breast high-about 4.5 feet) was calley floor. Symbols enclosed in a sampled at diameter is larger than the Since square represent stumps whose dim for most of the samples were taken from trees the invasion of trees appears to have started approximately 90 years ago. Diameter of the trees is closely correlated with age but this correlation is influenced by site. For example, trees marked "1" are from dry sites at the base of talus slopes and are much older than trees of comparable diameters from level portions of the Valley floor. Trees on very favorable sites (marked " 2 ") have a large d.b.h. in relation to their age. Understory trees, many of which are less than 10 inches d.b.h., are quite old. 
APPENDix TABle 3

RELATIVE ABUNDANCE OF SPECIES ON TEN FOREST SITES ON THE VALLEY FLOOR EXPRESSED AS PERCENTAGE OF TOTAL NUMBER OF PLANTS CONTRIBUTED BY EACH SPECIES*

\begin{tabular}{|c|c|c|c|c|c|c|c|c|c|c|}
\hline \multirow[b]{2}{*}{ Species } & \multicolumn{10}{|c|}{ Site } \\
\hline & A & $\mathrm{B}$ & $\mathrm{C}$ & $\mathrm{D}$ & $\mathrm{E}$ & $F$ & G & $\mathrm{H}$ & I & $\mathrm{J}$ \\
\hline & \multicolumn{10}{|c|}{ per cent } \\
\hline Carex spp................. & 4.0 & 0.0 & 10.0 & 1.3 & 4.0 & 3.3 & 13.3 & 0.0 & 0.0 & 0.0 \\
\hline 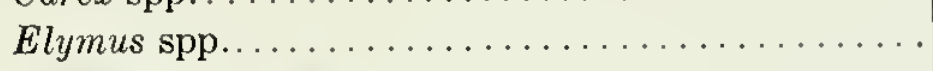 & 14.0 & 11.3 & 48.0 & 1.3 & 2.0 & 15.3 & 5.3 & 4.7 & 6.0 & t.0 \\
\hline 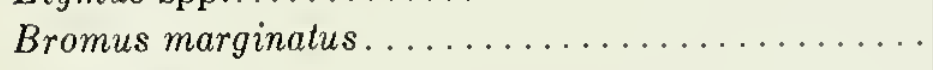 & 0.0 & 0.0 & 0.0 & 2.0 & 0.0 & 1.3 & 0.0 & 1.3 & 0.0 & 0.7 \\
\hline 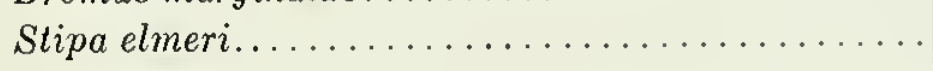 & 0.0 & 4.7 & 0.0 & 1.3 & 0.0 & 3.3 & 0.7 & 0.0 & 0.0 & 0.0 \\
\hline 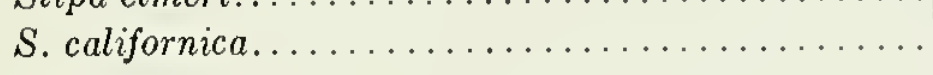 & 0.0 & 0.0 & 0.0 & 4.6 & 0.0 & 4.0 & 4.7 & 9.3 & 0.0 & 0.7 \\
\hline 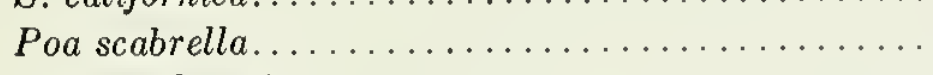 & 0.0 & 0.0 & 0.0 & 0.0 & 0.0 & 2.6 & 8.6 & 0.7 & 22.0 & 14.6 \\
\hline 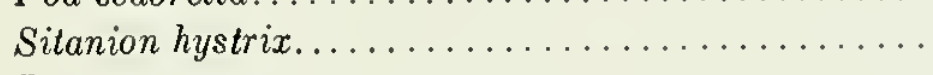 & 0.0 & 0.0 & 0.0 & 0.0 & 0.0 & 0.0 & 4.7 & 0.7 & 0.0 & 0.0 \\
\hline 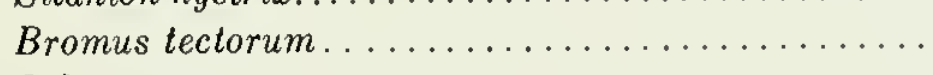 & 0.0 & 1.3 & 0.0 & 0.0 & 0.0 & 24.0 & 8.0 & 0.0 & 7.3 & 7.3 \\
\hline 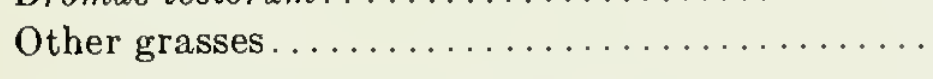 & 4.7 & 2.1 & 0.0 & 0.7 & 0.7 & 0.7 & 0.7 & 2.7 & 1.4 & 2.0 \\
\hline Pteridium aquilinum var. lanuginosum....... & 26.6 & 18.0 & 10.6 & 9.3 & 26.0 & 0.0 & 0.0 & 7.3 & 0.7 & 0.7 \\
\hline 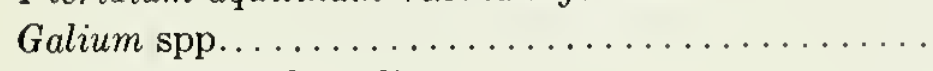 & 0.0 & 10.6 & 3.4 & 1.3 & 0.7 & 2.0 & 5.3 & 2.0 & 4.6 & 2.7 \\
\hline 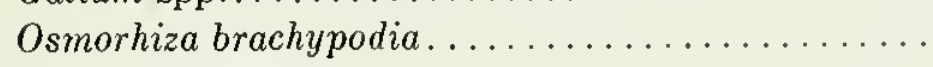 & 10.0 & 8.7 & 3.3 & 0.0 & 14.6 & 0.0 & 0.0 & 0.0 & 0.0 & 0.0 \\
\hline Kelloggia galioides............ & 2.6 & 2.0 & 1.3 & 22.0 & 0.7 & 0.0 & 0.0 & 0.0 & 0.0 & 0.0 \\
\hline Rumex acetosella............. & 3.3 & 4.7 & 0.0 & 0.0 & 0.0 & 0.0 & 0.0 & 0.0 & 0.0 & 1.3 \\
\hline 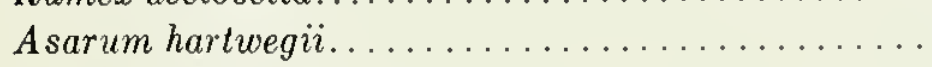 & 0.0 & 0.7 & 0.0 & 0.7 & 0.0 & 0.0 & 0.0 & 0.0 & 0.7 & 0.0 \\
\hline 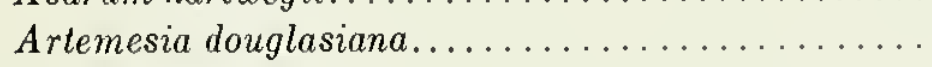 & 0.7 & 0.7 & 5.3 & 0.0 & 0.0 & 0.7 & 0.0 & 0.0 & 0.0 & 0.0 \\
\hline 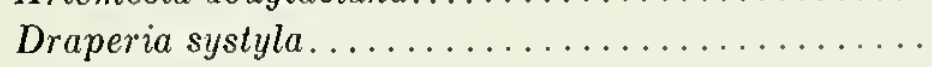 & 0.0 & 0.0 & 0.7 & 0.0 & 1.3 & 0.7 & 0.0 & 0.0 & 0.0 & 0.7 \\
\hline Gayophytum nuttallii............... & 0.0 & 0.0 & 0.0 & 0.7 & 0.0 & 1.3 & 1.3 & 0.0 & 0.0 & 1.3 \\
\hline Strepthanthus tortuosus................... & 0.0 & 0.0 & 0.0 & 0.0 & 0.0 & 0.0 & 0.7 & 0.0 & 0.0 & 12.0 \\
\hline 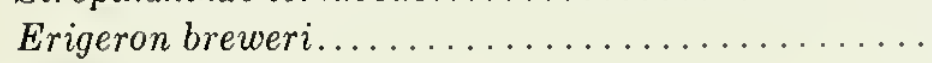 & 0.0 & 0.0 & 0.0 & 0.0 & 0.0 & 0.7 & 1.3 & 0.0 & 0.0 & 0.0 \\
\hline Lupinus greyii................ & 0.0 & 0.0 & 0.0 & 0.0 & 0.0 & 0.0 & 21.3 & 6.0 & 0.0 & 0.0 \\
\hline Lessingia leptoclada.............. & 0.0 & 0.0 & 0.0 & 0.0 & 0.0 & 2.0 & 6.7 & 0.0 & 0.0 & 0.0 \\
\hline Brickellia californica.................... & 0.7 & 0.0 & 0.0 & 0.0 & 0.0 & 0.7 & 0.0 & 0.0 & 7.3 & 6.6 \\
\hline Penstemon laetus............. & 0.0 & 0.0 & 0.0 & 0.0 & 0.0 & 0.0 & 0.0 & 0.0 & 0.7 & 5.3 \\
\hline Eriophyllum confertiflorum............... & 0.0 & 0.0 & 0.0 & 0.0 & 0.0 & 0.0 & 0.0 & 0.0 & 0.0 & 0.7 \\
\hline 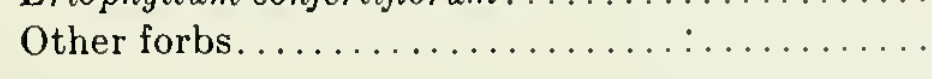 & 2.1 & 2.0 & 4.0 & 4.8 & 2.1 & 6.1 & 10.7 & 4.8 & 5.3 & 0.0 \\
\hline Rubus leucodermis......................... & 0.0 & 12.6 & 3.3 & 0.7 & 4.0 & 0.0 & 0.0 & 0.0 & 0.0 & 0.0 \\
\hline 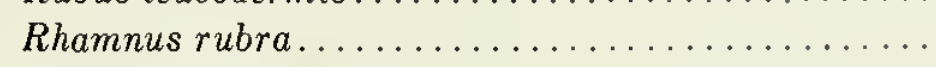 & 0.7 & 0.0 & 0.7 & 0.7 & 0.0 & 0.0 & 0.0 & 9.3 & 0.0 & 0.7 \\
\hline 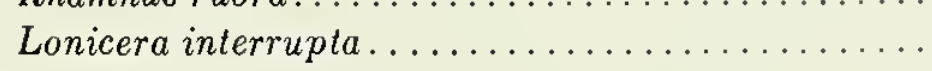 & 0.0 & 0.0 & 0.0 & 0.0 & 0.0 & 0.0 & 0.0 & 1.3 & 2.7 & 0.7 \\
\hline 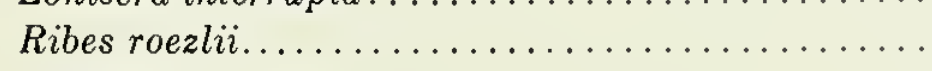 & 0.0 & 0.0 & 0.0 & 0.0 & 0.7 & 0.0 & 0.7 & 0.0 & 0.7 & 0.7 \\
\hline 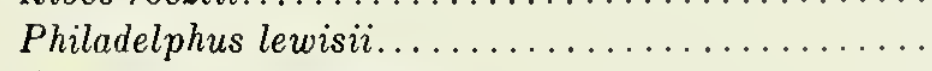 & 0.0 & 0.0 & 0.0 & 0.0 & 0.0 & 0.0 & 0.0 & 0.0 & 4.0 & 0.0 \\
\hline 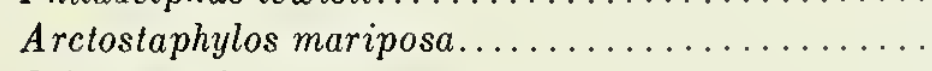 & 0.0 & 0.0 & 0.0 & 0.0 & 0.0 & 0.0 & 0.0 & 7.3 & 0.0 & 1.3 \\
\hline 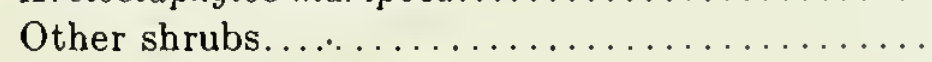 & 0.7 & 1.3 & 0.7 & 0.0 & 0.0 & 0.0 & 0.0 & 0.0 & 0.0 & 0.7 \\
\hline
\end{tabular}




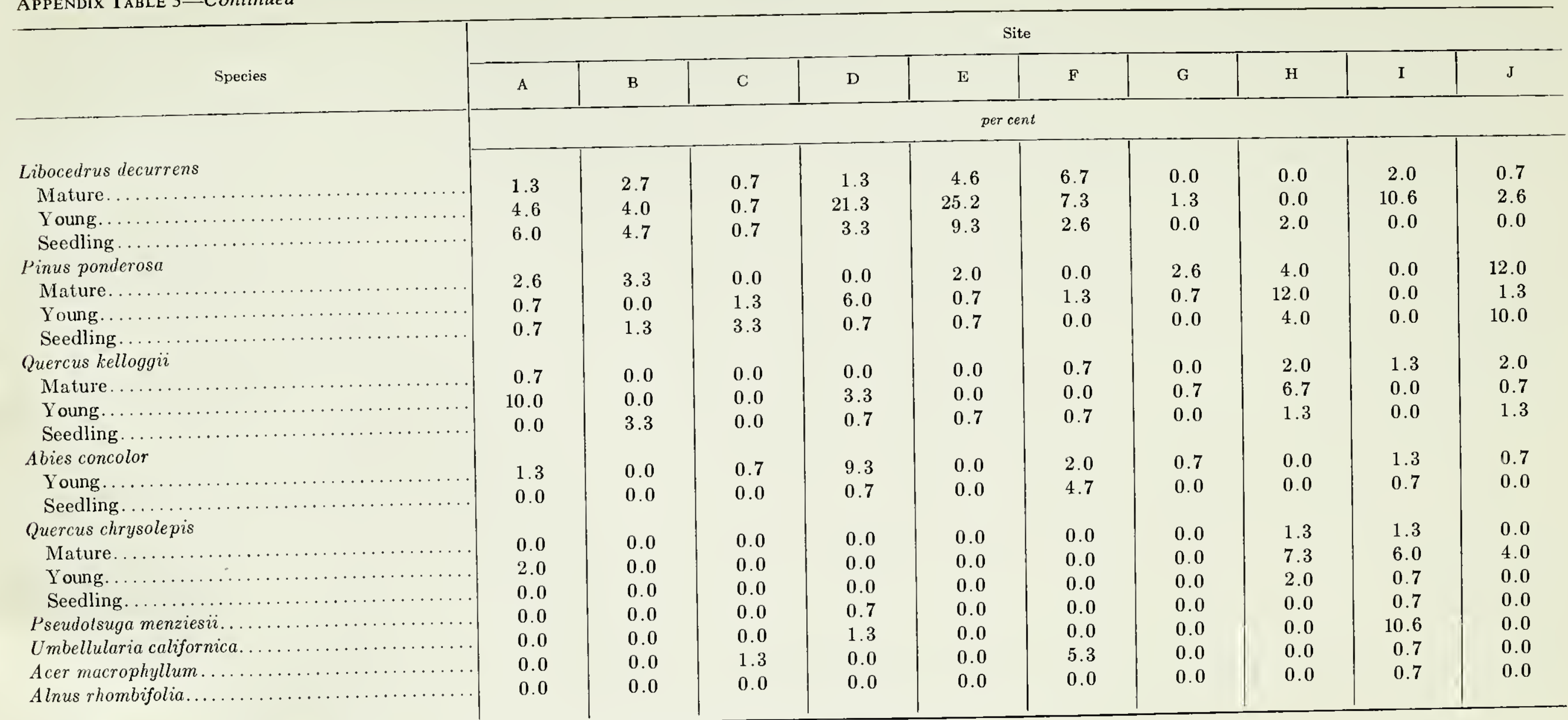

* Calculated from rooted frequency as determined by 150 step-point samples on each site (see figure 16 for site locations). 
APPENDix TABLE 4

RELATIVE ABUNDANCE OF SPECIES ON THE MAJOR MEADOW AREAS IN YOSEMITE VALLEY EXPRESSED AS PERCENTAGE OF TOTAL NUMBER OF PLANTS CONTRIBUTED BY EACH SPECIES*

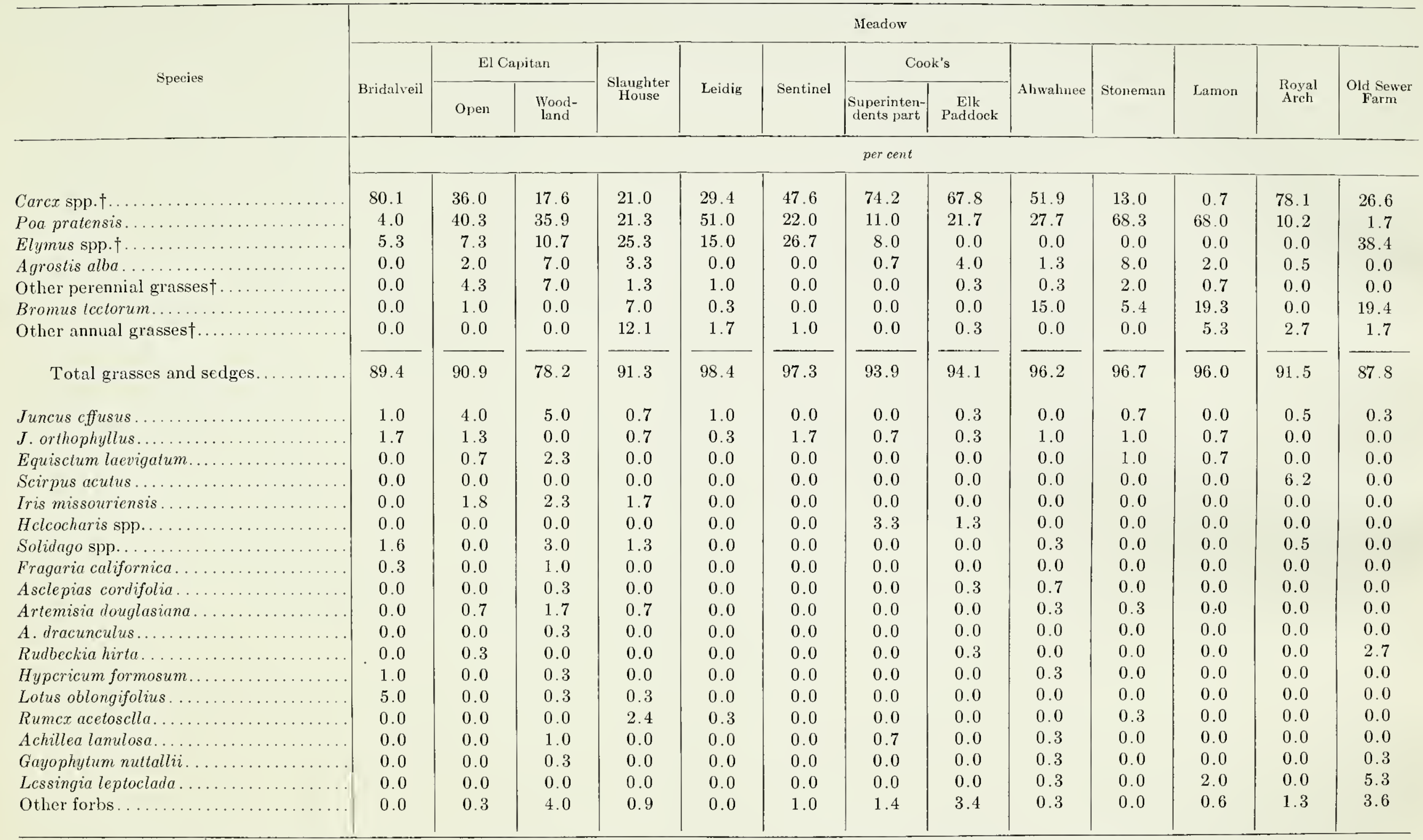

* Calculated from rootcd frequency as determined by 300 step-point samples in all meadows except Lamon (150) and Royal Arch (225) (see figure 16 for location of meadows).

See appendix I for names of species. 
APPENDIX TABLE 5

INTRODUCED PLANTS FOUND IN YOSEMITE VALLEY*

\section{Trees and Shrubs}

Acer saccharophorum

Cercis occidentalis

Hedera helix

Malus sylvestris

Parthenocissus quinquefolia

Prunus cerasus

Pyrus communis

Robinia psendocacia

Rubus recurvans

Sequoia gigantea

Syringa valgaris

Ulmas anericana

Vitis spp.

\section{Forbs}

Anthemis cotula

Brassica kaber var. piunutifida

B. campestris

Capsella bursa-pastoris

Cardaria draba

Cerastrium viscosun
C. vulgatum

Chenopodium album

C. botrys

Chrysanthemum leucanthemum

Cirsium vulgare

Cuicus benedictus

Convolvulus arvensis

Conyza canadensis

Digitalis purpurea

Erigeron strigosus

Erodiun botrys

E. cicutarium

Galium aparine

Glecoma hederacea

Humulus lupulus

Hypericum perforatum

llex aquifolium

Lactuca serriola

Malva parviflora

Mentha spicata

Mullugo verticillata

Pimpinella anisum

Plantago lanceolata
Plantago major

Polygonum aviculare

$P$. convolvulus

P. Lapathifolium

P. persicaria

Portulaca oleracea

Pranella vulgaris

Raphanus sativus

Rudbeckia lirta var. pulcheirinua

Rumex acetosella

R. crispus

Sisymbrium altissimumn

S. officinale

Taraxacumn valgare

rhlaspi arvense

Trifoliun repens

Verbascum thapsus

Veronica serpyllifolia

\section{Grasses}

Agrostis alba

A. alba var. palustris

Avena fatua
Bromus commutatus

B. inermis

B. mollis

B. rigidus

B. rubens

B. secalinus

B. tectorum

Dactylis glomerata

Digitaria ischaemum

D. sanguinalis

Eragrostis megastachya

E. pilosa

Festuca dertonensis

F. clatior

Holcus lanatus

Hordeum stebbinsi

Lolium pereme

Plileum pratense

Poa pratensis

Setaria lutescens

S. viridus

:k List compiled from Durant (1927), McDonald (no date), Woodham (1927), Michael (1929, 1935), Carlson (1932), Goen (1932), Lillard (1948), Bryant (1951), and sheets in the Yosemile Museum 
APPENDix TABLE 6

RELATIVE ABUNDANCE OF SPECIES ON THE SITE OF THE OLD VILLAGE STORE EXPRESSED AS PERCENTAGE OF TOTAL NUMBER OF PLANTS CONTRIBUTED BY EACH SPECIES. (DATA GATHERED 2 YEARS AFTER REMOVAL OF THE STORE.)*

\begin{tabular}{|c|c|}
\hline Species & Per cent \\
\hline Festuca rubra.............. & 31.3 \\
\hline Elymus spp............. & 22.7 \\
\hline Poa pratensis............. & 10.7 \\
\hline Agrostis alba............ & 1.3 \\
\hline Sitanion hystrix.......... & 0.7 \\
\hline Carex spp............... & 1.3 \\
\hline Bromus rigidus.......... & 1.3 \\
\hline B. tectorum............ & 0.7 \\
\hline Sisymbrium altissimum. . & 22.7 \\
\hline Lactuca serriola........ & 1.3 \\
\hline Capsella bursa-pastoris. . . & 0.7 \\
\hline Chenopodium botrys........ & 0.7 \\
\hline C. album............... & 1.3 \\
\hline Rumex acetosella.......... & 1.3 \\
\hline Artemesia douglasiana..... & 0.7 \\
\hline Unidentified............. & 1.3 \\
\hline
\end{tabular}

* Calculated from rooted frequency as determined by 150 step-point samples.
APPENDIX TABLE 7

DEGREE OF SOIL COMPACTION INSIDE AND OUTSIDE CAMPGROUNDS AS MEASURED BY A SOIL PENETROMETER:

\begin{tabular}{|c|c|c|c|c|c|}
\hline Location & Soil & Area & Use & $\begin{array}{l}\text { Number of } \\
\text { samples }\end{array}$ & $\begin{array}{l}\text { Mean compac- } \\
\text { tion value }\end{array}$ \\
\hline Camp 14 east end.. & sandy-loam & $\begin{array}{l}\text { inside } \\
\text { outside }\end{array}$ & $\begin{array}{l}\text { heavy } \\
\text { moderate }\end{array}$ & $\begin{array}{l}39 \\
10\end{array}$ & $\begin{array}{l}2.82 \\
1.16\end{array}$ \\
\hline Camp 14 central part. & sandy-loam & $\begin{array}{l}\text { inside } \\
\text { outside }\end{array}$ & $\begin{array}{l}\text { heavy } \\
\text { moderate }\end{array}$ & $\begin{array}{l}40 \\
38\end{array}$ & $\begin{array}{l}2.34 \\
1.40\end{array}$ \\
\hline Camp 14 west end. & sandy & $\begin{array}{l}\text { inside } \\
\text { outside }\end{array}$ & $\begin{array}{l}\text { heavy } \\
\text { moderate }\end{array}$ & $\begin{array}{l}50 \\
50\end{array}$ & $\begin{array}{l}1.35 \\
0.48\end{array}$ \\
\hline Camp 11 west end... & sandy-loam & $\begin{array}{l}\text { inside } \\
\text { outside }\end{array}$ & $\begin{array}{l}\text { heavy } \\
\text { moderate }\end{array}$ & $\begin{array}{l}50 \\
50\end{array}$ & $\begin{array}{l}2.78 \\
1.24\end{array}$ \\
\hline East of Yellow Pine Beach. & sandy & forest & very light & 50 & 0.55 \\
\hline North of El Capitan Beach. & $\begin{array}{l}\text { sandy to } \\
\text { sandy-loam }\end{array}$ & forest & very light & 50 & 0.60 \\
\hline
\end{tabular}

The larger the value of the means the greater the degree of compaction. Differences between the means of samples from inside and outside the campgrounds were highly significant.

Co-aperative Extensian wark in Agriculture ond Hame Ecanomics, College of Agriculture, University af Colifarnio, and United States Department af Agriculture co-aperating. Distributed in Co-aperative Extensian wark in Agriculture ond 8 , and June 30, 1914. Gearge B. Alcarn, Directar, Colifornia Agricultural Extensian Service.

$2 m-7,64($ E5202L) V.L. 

